ONTTED STATES DEPARTMENT OF THE INTERIOR

GEOLOGICAL SURVEY

\author{
SUMMARY OF REFERENCES TO MINERAL OCCURRENCES \\ (OTHER THAN MINERAL FUELS AND CONSTRDCTION MATERIALS) \\ IN THE SUMDUM AND TAKU RIVER QUADRANGLES, ALASKA
}

By

Edward H. Cobb

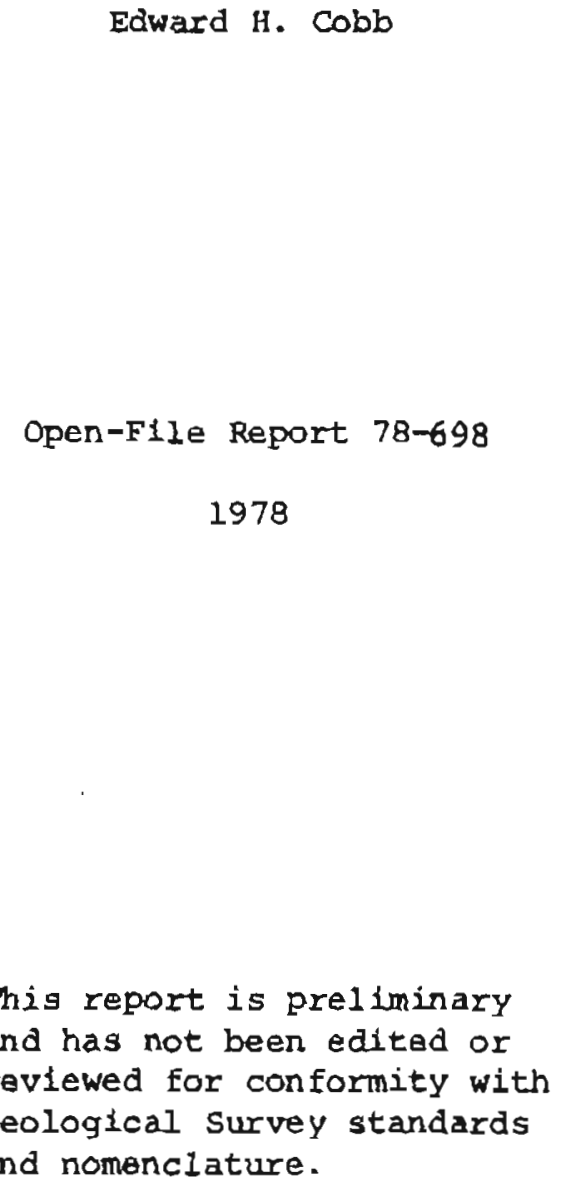

This report is preliminary and has not been edited or reviewed for conformity with Geological survey standards and nomenclature.

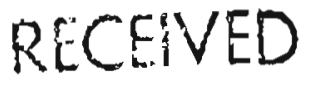

\author{
JuL 281075 \\ Dir: or Geologisal Survey \\ anchurage
}


Introduction

These sumaries of references are designed to aid in library research on metallic and nonmetallic (other than mineral fuels and construction materials) mineral occurrences in the Sumdun and Taku River quadrangles, Alaska. All references to reports of the Geological Survey, to most reports of the U.S. Bureau of Mines, and to mogt reports of the state of Alaska Division of Geologlcal and Geophysical Surveys and its predecessor State and Territorial agencies released before May 1, 1978, are gumarized. Certain, mainly statistical, reports such as the annual Minerals Yearbook of the U.S. Bureau of Mines and most biennial and annual reports of the State of Alaska Division of Geological and Geophysical Surveys and its prececessor state and Territorlal agencies are not included.

This report is divided into three parts: a section made up of summarles of references arranged alphabetically first by guadrangle and second by occurrence name; a section that lists symonyms for names in the first section, claim names, and the names of operators and owmers of mines and prospects; and a section that 11sts, by author, all references sumarized in the first section. 
isnine

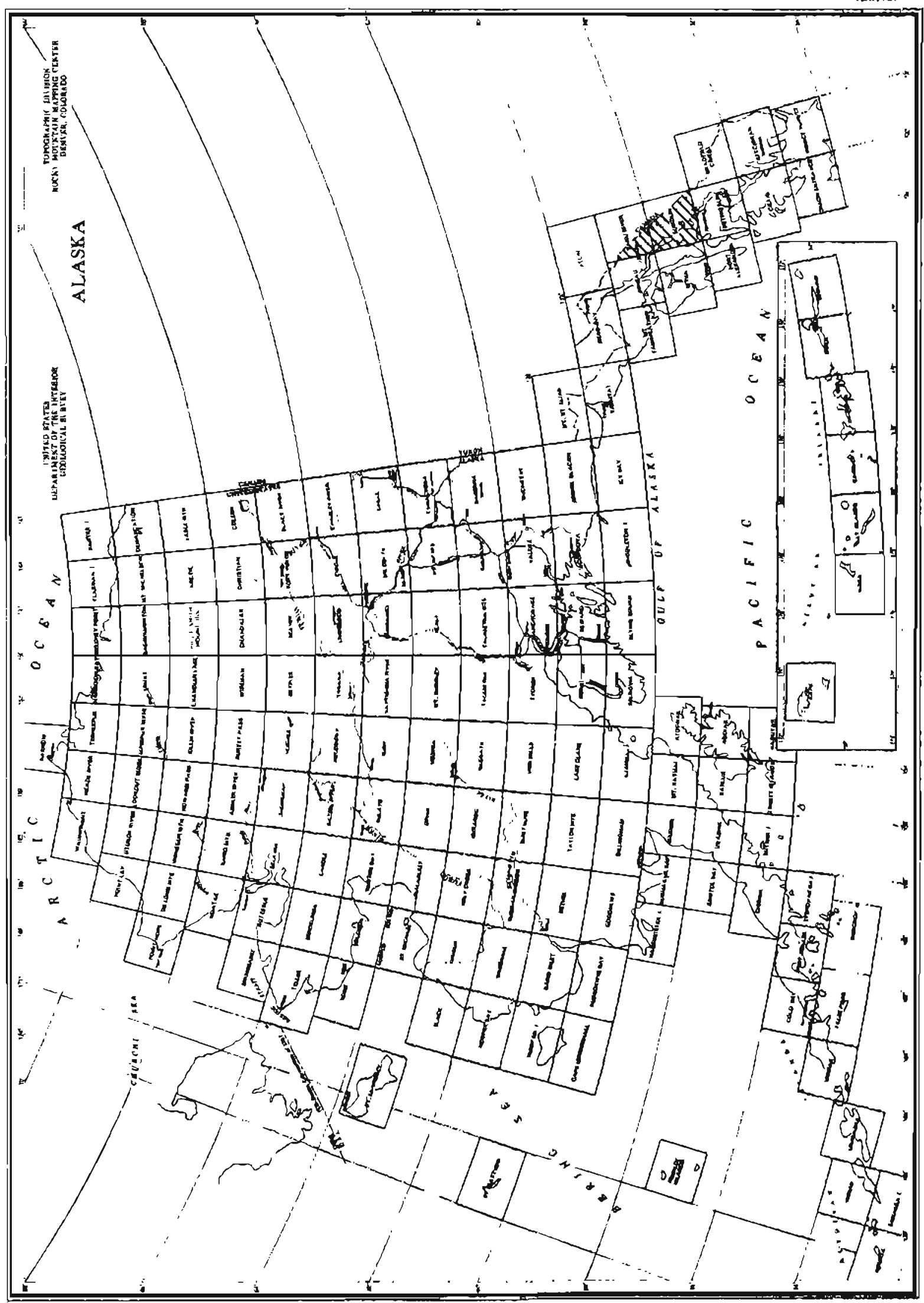




\section{Sumbaries of References}

For each minexal occurrence there is a page that gives the name of the occurrance; the mineral comodities present (listed alphabetically for mallic conmoditles and then for nonmetallic commoditles) [FM is used for uranium and(or) thorium determined chemically or prosent as a constituent of an identifled mineral other than monazite]; the mining alstrict (Ransome and Kerns, 2954) in which the occurrence is located, the name of the 1:250,000-scale topographic quadrangle; coordinates (as descrdbed by cobb and Kachadoorian, 1961, p. 3-4); the metallic mineral resources map number (cobb, 1972, in the reference 1ist for each quadrangle) and the occurrence number on that map if the occurrence is shown; and the latitude and longltude of the occurrence. These data, presented at the top of the page, are followed by a short, general summary of the published information on the occurrence. This is followed (continued on additional pages, if necessary) by moxe detailed sumaries, arranged chronologically, of all references to the occurrence. Material in brackets is interpretive or explanatory and is not in the sumarized reference.

Proper names of mines, prospects, and other mineral occurrences ugually are given if such names appear in the reports sumarized. If a deposit does not have such a name or has been known by many names, but is near a named goographic feature, the name of that feature is shown in parentheses in Iieir of a proper name. If a deposit has no proper name and is not near a named geographic feature, it is titled "Unnamed occurxence" and appears at the end of the Iist. If a part of a proper name is not Qiways used in a refezence, that part of the name is shown in parentheses. This is most comwon in company names and in place names with minor variations in spelling. 
Citations are givan in standard bibliographic format with the exception that references to reports and naps in numbered publication series also show, in parentheses, an abbreviation for the report or map series and the report or map nunber. Abbreviations used are:

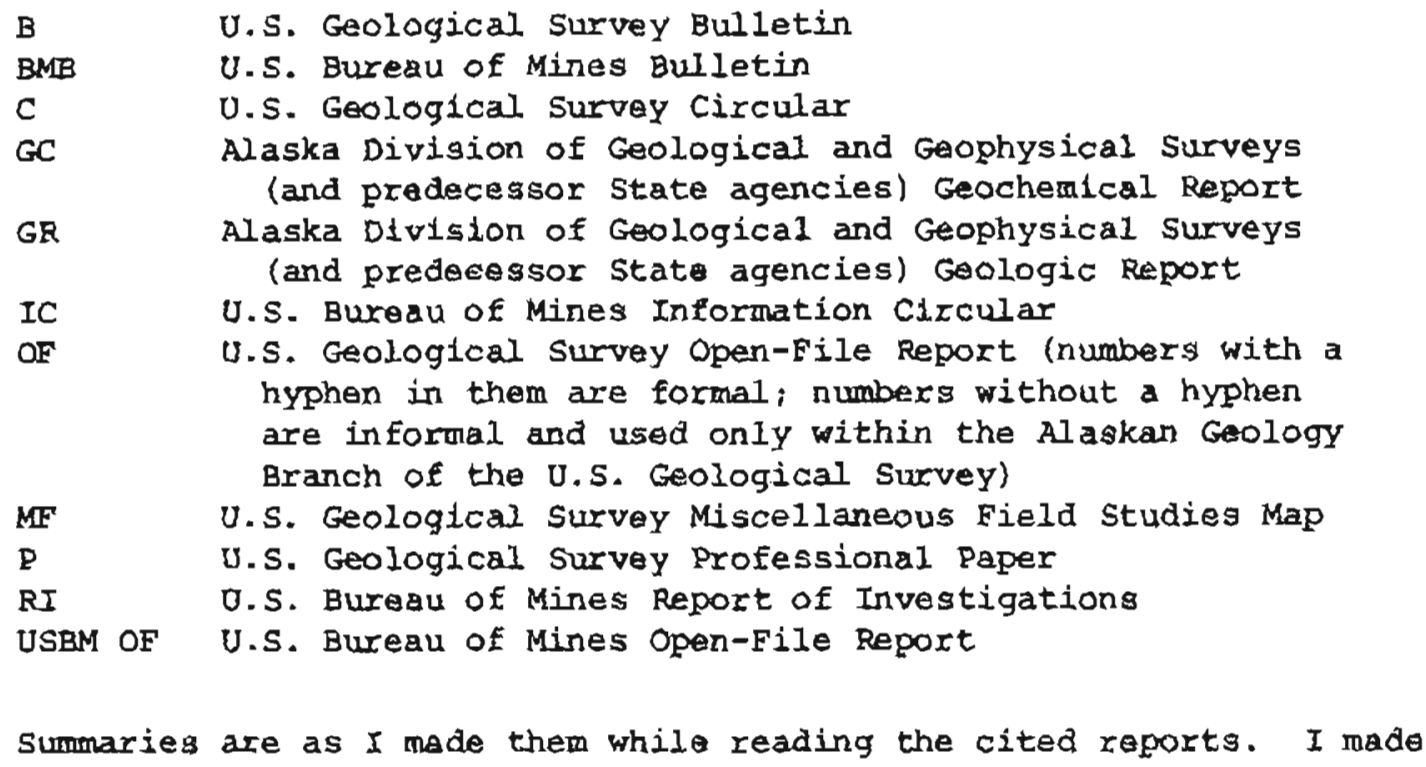

no attempt to use complete sentences and did not edt for grammatical consigtency, although I have tried to vait out ambiguities.

References cited only in these introductory paragraphs are:

Cobb, E. H., and Kachadoorian, Reuben, 1961, Index of metallic and nonmetallic mineral deposits of Alaska compiled from published reports of Federal and stato agencles through 1959: 0.5. Geol. Survey Bull. $1139,363 \mathrm{p}$.

Ransome, A. L., and Korns, W. H., 1954, Names and definitions of regions, districts, and subdistricts in Alaska (used by the Bureau of Mines in statistical and economic studies covering the mineral industry of the Territory): U.S. Bur. Mines Inf. Circ. 7679, 91 p. 
Arm

Juneau district
Sumdum $(3.85,16.25)$

$57^{\circ} 56^{\prime} \mathrm{N}, 133^{\circ} 35^{\prime} \mathrm{N}$

Sumnary: Claims staked in 1974 on ixon-stained gneiss in a steep gorge. pyrrhotite in float sample that contained $230 \mathrm{ppm} \mathrm{Cu,} 400$ ppm $\mathrm{Zn}$, and $15 \mathrm{ppm} \mathrm{pb}$.

Brew and others, 1977 (OF 77-649), p. 188 - In Sumdun Glacier mineral belt.

p. 191 -- Iron-stained gneiss in a steep gorge. 4 claims recorded in 1974. Sample of float from stream contained pyrthotite and quartz; rusty gneiss. Atomic absorption showed 230 ppm Cu, 15 ppm $\mathrm{Pb}$, and $400 \mathrm{ppm} \mathrm{Zn}$; spec. analysis showed 3 ppm Ag (Table 25, sample 5KO5O). 
Summary: As much as 90 ppm eU (16.1 ppm U) in samples of pegmatitic lenses in granodiorite. Deposit not of economic interest; too small and too low grade.

Eakins, 1925 (GR 44), p. 34-39-- Small pegmatite lenses in dioxite contain a uranium mineral (uraninite?); analysis of a sample collected by owner showed $0.032 \%$ U. Pegmatite lenses have about 10 times background (diorite) radioactivity. 2 samples collected in 1970 assayed 35 and 45 porn $U$.

Brew and others, 1977 (OF 77-649), p. 235-236-- Roference to above. USGS and USBM fowd 4 elliptical altered zones containing pegmatitic albite lenses in granodiorites from 45 x $35 \mathrm{ft}$. to 120 x 20 it. in size. Uranium values in chtp samples ranged from 0.2 ppm to 16.1 ppm; also traces of $\mathrm{Cu}, \mathrm{Ag}$, and $\mathrm{Pb}$. Deposit appears to be too small and too low grade to be of economic interest.

p. 252 - Erospect subeconomic. Up to $90 \mathrm{ppm}$ eU. 
Bluebira

Petersburg district
Copper, Gold, Lead, Silver, Zlne

Sundum $(5.85,10.6)$

$57^{\circ} 36^{\prime} \mathrm{N}, 133^{\circ} 23^{\prime} \mathrm{W}$

surmary: old prospect with probably several hundred feet underground workings (now flooded) and an open cut. Quartz vein $1.6 \mathrm{ft}$. thick contalns pyrite, sphalerite, chalcopyrite, galena, gold, and silver. Country rock is graphitic schist. No record of production.

Brew and others, 1977 (OF 77-649), p. 181 -- 4 mi. SE of Sumdum Chief. p. 183-186 -- Open cut and flooded shaft, dump from which suggests about $400 \mathrm{ft}$. of underground workings. Country rock is calcaroous graphitic schist. Quartz vein in open cut and creek bed is $1.6 \mathrm{ft}$. thick and contains abundant pyrite, sphalerite, chalcopyrite, and galena in hanglng wall portion, a sample from a small part of which contained $2.1 \mathrm{ppos} A \mathrm{Al}$ and $296.5 \mathrm{ppm}$ Ag by fire assay, Geologic setting similar to that at sumdum Chief.

p. 263 -- cold-bearing quartz veing with mineralogy and host rock similar to those at Sumdum Chlef. No reported production. 
(Bushy Islands)

Petersburg district
Copper, Silver, zinc

Sumdum $\cdot(5.3,12.4)$

$57^{\circ} 43^{\prime} \mathrm{N}, 133^{\circ} 26^{\prime} \mathrm{W}$

Summary: Quartz stringers no more than $1.5 \mathrm{ft}$. thick in phyldite contain traces of chalcopyrite, sphalerite, and malachite. chip samples across $5.2 \mathrm{ft}$. contained $0.015 \mathrm{oz}$. silver a ton.

Brew and others, 1977 (OF 77-649), p. 218 -- Copper-stained quartz stringers 0.05-1.5 ft. wide in phyllite locally contain traces of chalcopyrite, sphalerite, and malachite. Chip sample across 5.2 ft. of phyllite and quartz stringers contained $700 \mathrm{ppm} \mathrm{Cu}, 1,600$ ppm $\mathrm{Zn}$, and $0.015 \mathrm{oz}$. Ag per ton. 
Summary: Quartz stringers in a mineralized shear zone $140 \mathrm{ft}$. wide in quartz diorite contain pyrite, galena, and smaller amounts of sphalerite and chalcopyrite. Average tenor of shear zone reported to be about $0.145 \mathrm{oz}$. gold per ton; the richest part about 5-1/2 ft. wide 1 s reported to carry about $0.774 \mathrm{oz}$. gold per ton. No data on development.

Budaington, 1923 (B 739), p. 68 -- Mineralized shear zone 140 ft. wide reported to consist of sulfide-bearing quartz stringers in quartz diorite. Minerals in veins include pyrite and galena with a little sphalerite and chalcopyrite. Full width of zone averages about $\$ 3$ [about $0.145 \mathrm{oz.}$ ] a ton in gold. Rlchest part (5-1/2 ft. wide) is reported to carry about $\$ 16$ [about 0.774 oz.] a ton.

Berg and cobb, 1967 (B 1246), p. 191 -- Summary of above. 
Crystal

Juneau district

$M-425,100-1$
Gold

Sundum (1.8, 16.9)

$57^{\circ} 58^{\prime} \mathrm{N}, 133^{\circ} 48^{\prime} \mathrm{W}$

Sumary: Quartz flssure vein(s) about 4 ft. thick in amphibolite (probably derlvea from andesite or porphyritic basalt) mined from 1899 to 1905 and sporadically until early 1930's. Production from Erystal and nearby Erlday mines, 1899-1905 probably was at least 2,000 oz. of gold; no data on later production. Ore mainly pyrite, some of which had on crystal faces small crystals and particles of visible gold. Incluaes refexences to Daisy Bell and to lode gold near Snettisham.

Spencer, 1904 (B 225), p. 36 -- Has been considerable prospecting on south side of Port snettisham neax contact between greenstone and overlying shales; one mine has produced a few thousand dollars [1903].

Wright and Wright, 1905 (B 259), p. 53 -- Snett1sham mine and 20-gtamp mill operated for most of 1904. "...relatively [probably as compared to mines at Juseaul small deposit..."

Spencer, 1906 (B 287), P. 47-48 - Discovered 1895. quartz ledge l-10 ft. wide (average about $4 \mathrm{Et.)}$ In what appears to be a wide andesite dike; quartz and included andesite fragments carry gold. Many large pyrite cubes in druses in quartz). gold (some crystalline) on sldes of pyrite cubes. Mining and milling (10 stamps), 1901-02, said to have produced about $\$ 25.000$ [about 1,210 fine oz.] in gold. Larger scale development began in 1903; about 1,000 Et. of workings; developed ore stoped and milled by end of 1904. [No data on amount of production.] Plan to remove equipment in 1905.

Wright and wright, 1906 (B 284), p. 40-41-- No mining, 1905; ran out of ore.

Wright, 1907 (B 314), p. 58 -- A 11ttle mining and milling, 1906.

Wright, 1908 (B 345), p. 90 -- Considerable ore run through 5-stamp mill, 1907.

Wright, 1909 (B 379), p. 71-72 -- Stoping from upper level toward surface; voin $18 \mathrm{in}$. to $5 \mathrm{ft}$. thick. Ore mined from surface on Daisy Bell claim. Mill treated 15 tons of ore a day for 50 days, 1908.

Kropf, 1910 (B 442), p. 139 -- Mining and milling. 1909.

Knopf, 1911 (B 480), p. 97 - Mining suspended and mill closed, sept. 1910. Ore body was a quartz vein about $4 \mathrm{ft}$. thick in zoisite amphibolite that was probably derived from andesite porphyry; vein dips $10^{\circ}-40^{\circ}$ NE.

Knopf, 1912 (8 502), p. 39-40 - Quartz fissure vein in schistose zoisite anphibolite that appears to have been derived from a porphyritic basalt in which the origlnal feldspar phenocrysts were saussuritized and drawn out. Chemical analysis and petrographic description of rock are given. Near vein amphibolite is altered to a rock that is mainly albite; minor amounts of quartz, pyrite, carbonate, chlorite, and apatite.

Brooks, 1913 (B 542), p. 33 - 100-ft. tunnel and 40-ft. rajse completed on Daisy Bell claim; discovery of 4-ft. ore body reported, 1912. 
Crystal -- continued

Martin, 1920 (B 712), p. 30 -- Idle, 1918.

Brooks, 1922 (8 722), p. 36 -- A little ore milled at Daisy Bell, 1920.

Brooks, 1923 (B 739), p. 21 -- Small-scale productive work, 1921.

Brooks and Capps, 1924 (B 755), p. 24 - Mine cloged, 2922.

Thorne and hells, 1956 (RI 5195), p. 6 -- Crystal and Friday gold mines operated by Alaska Snettisham Gold Mining Co., 1899-1905. Sporadic gold mining in area until early $3930^{\prime} \mathrm{s}$.

Berg and cobb, 1967 (8 1246), p. 155 - Crystal and Friday mines probably produced about 2,000 02 . gold between 1899 and 1905 ; sporadic mining intil early $1930 \mathrm{~s}$, but no data on production after 1905. Lodes in slate near its contact with diorite; quartz veins containing pyrite and gold. Ore mainly pyrite, in much of which small crystals and particles of gold were visible. 
Friday

Juneau district

MF-425, I0C. 2
Gold. Iron

Sundum $(2.15,17.3)$

$57^{\circ} 59^{\prime} \mathrm{N}, 133^{\circ} 46^{\prime} \mathrm{W}$

Sumary: Irregular quartz body 1-6 ft. wide in altered slate near a diorite intrusive body. Mined from 1899 to 1904. Low-grade ore consisting of auxiferous pyrite and much magnetite. See also Crystal.

Spencer, 1906 (B 287), p. 47 -- Irregular quartz ledge 1-6 ft. wide in altered slate near diorite intrusive. Developed by 2 tunnels $750 \mathrm{ft}$. and $600 \mathrm{ft}$. long, pits, and open cuts. Operations began in 1899 and ceased in 1904. Ore is auriferous pyxite with much magnetite; low grade. [No data on production.]

Thorme and Wells, 1956 (RI 5195), P. 6 -- See entry on Crystal sheet. Berg and Cobb, 1967 (B 1246), p. 155 -- See entry on Crystal sheet. 
Gold Nest

Juneau district
Gold(7), Silver

Sundun $(3.7,16.5)$

$57^{\circ} 57^{\prime} \mathrm{N}, 133^{\circ} 36^{\prime} \mathrm{W}$

Sumary: Brecciated pyritic quartz veins contain a little silver. Atomic absorption showed as much as 7.0 ppm gold, but this was not confirmed by fire assay. Cladms recorded 1n 1912.

Brew and others, 1977 (OF 77-649), p. 188 -- In Sumdum Glacier mineral belt. Near pass between Tracy Arm and Lower Sweetheart Lake.

p. 191 -- Brecclated pyxitic quartz vein is 3 ft. thick. Was explored with a short open cut. claims recorded in 1912. A chip sample and a selected grab sample of float (Table 25, samples 3KI69 and $3 \mathrm{~K} 171$ ) contained (by spectrographic and atomic-absorption analyses) 0.5-1.5 ppm Ag and 0.10-7.0 ppm Au, fire assays detected no gold in either and $3.1 \mathrm{ppm} \mathrm{Ag}$ in one. 
Holkham Bay

Petersburg distrlct

MF-125, 10c. 10 copper, Gold, Lead, Silver

Sumdun $(6.0,11.05)$

$57^{\circ} 38^{\circ} \mathrm{N}, 133^{\circ} 2^{\prime \prime} 2^{\prime} \mathrm{w}$

Sumary: Quartz vein about $2 \mathrm{ft}$. thick in schist developed by drift $170 \mathrm{ft}$. long and 3 stopes, which probably yielded no more than $50 \mathrm{oz}$. of gold, and several pits. A second vein $6 \mathrm{ft}$. wide was explored by plts and shallow shafts. Minerals in vein (and included country rock) that was developed include galena,pyrite, arsenopyrite, chalcopyrite, and free gold. Analyses indlcated traces of gilvar. Average gold content of samples from drift was $0.094 \mathrm{oz}$. per ton. Deposit discovered in about 1900; most work before 1909. Regtaked as recentily as 1956.

Spencer, 1906 (B 287), p. 45 -- Mineralized quartz ledge in schist belt carries values in gold, silvar, and copper. $300 \mathrm{ft}$. of development work. Wright and Wright, 1906 (B 284), p- 41 -- Same as above.

Wright, 1907 (g 314), p. 58 -- Underground development, 3906. Deposit is a mineralized quartz lode in schlst within $2 \mathrm{mi}$. Of coast Range intrusive belt. Ore minerals are Eree gold, galena, pyrite (some arsenical) and chalcopyxite, all in both quartz veinlets and enclosed fragments of country rock.

Wright, 1908 (B 345), p. 90 -- Development continued, 1907.

Wright, 1909 (B 379), p. 72 -- Development continued, 1908 .

Berg and Cobb, 1967 (B 1246), p. 190 -- Auriferous lode was explored by several hundred feet of underground workings; no known production. Lode is in schist adjoining coast kange batholith, composed of quartz veinlets and fragments of country rock containing galena, pyrite, arsenopyrite, chalcopyrite, and gold.

Brew and others, 1977 (OF 77-649), p. 6r7 - Gold prospect on Endicott Peninsula. Similar to Windham Bay mines and prospects. Had small production.

p. 166-168 -- Main workings (on a quartz vein 1-2 ft. thick) consist of a 170-ft. drift (in which the vein pinched out) and 3 stope raises; stoped out material probably contained 20-50 oz. gold. Vein traced for at least $400 \mathrm{ft}$. by pits. Channel samples contain an average of $0.094 \mathrm{oz}$. of gold per ton and traces of silver. Another vein about $6 \mathrm{ft}$. thick was explored with several shallow shafts and pits. Wall rocks of mined vein are sheared graphitic schists that in places interfinger with the vein. Discovered in about 1900 and periadically restaked, most recently in 1956.

p. 263 -- Deposit has long been known. 
Petersburg district

Sumdum $(5.85,10.8)$

MF-425, IOC. 11 $57^{\circ} 37^{\circ} \mathrm{N}, 133^{\circ} 23^{\prime} \mathrm{W}$

Sumary: Gold- and sulfide-bearing guartz veins in black slate. Deposit resembles that at sumdum chief mine.

Spencer, 1906 (B 287), P. 40 -- Prospect between Sundum and windham Bay.

p. 42 -- Auriferous quartz ledges in slate belt resenble Sumdun chief. Very Iittle work has been done. [Name of prospect not used.]

Berg and Cobb, 1967 (B 2246), p. $191-$ Gold-and sulfldo-bearing quartz veins in black slate, resembles sumam Chief rather than the closer Windham Bay lodes.

Brew and others, 1977 (OF 77-649), p. 182 -- Reference to Spencer, 1906 (B 287), p. 40, 42 . 
Petersburg district

Sumcium $(5.05,8.5)$

$M F-425,10 \mathrm{C}, 16$

$57^{\circ} 29^{\prime} \mathrm{N}, 133^{\circ} 28^{\prime} \mathrm{W}$

Sumbary: Quartz veins contain sphalerite, pyrite, and tetrahedrite(?). Called a lode gold prospect in one reference, but analyses of samples showed no gold. Native antimony reported.

Alaska Department of Mines, 1957, p. 33 -- Iode gold prospect being actively developed by Kloss \& Davis at sunget cove during biennium 19551956.

p. 48 - Native antimony is present.

Clark and others, 1970 (OF 434), p. 3, 7 -- Samples of quartz veins contain sphalexite, pyrtte, and tetrahedrite(?). Ag as high as 7 ppm; no Bu. 
Admiralty district

Sumdum $(0.2,8.45)$

ME-425, 10c. 17

$57^{\circ} 29^{\prime} \mathrm{N}, 133^{\circ} 59^{\circ} \mathrm{W}$

Sunmary: Copper and nickel oxides in shear zone 150-200 ft. wide reported. copper minezalization reported along a parallel shear zone. Includes reference to copper-nickel minerals in kyd Fim. on north shore of bay.

Herbert and Race, 1964 (GC 1), P. 13 -- Kloss reported that a trench across a shear zone 150-200 ft. wide showed small amounts of copper and nickel oxides; copper mineralization along parallel shear zone. Berg and Cobb, 1967 (B 1246), p. 141 -- Same as above.

Race and Rose, 1967 (GC 8), p. 2 -- Reference to Herbert and Race, 1964 (GC 1) [name of prospect not used; called Hyd $F_{m}$. On north shore of Gambier Bay]. 
(Point Astley)

Petersburg district

MF-425, loc. 7
Copper, Lead, Silver, zine

Surodum $(3.45,12.35)$

$57^{\circ} 42^{\prime} \mathrm{N}, 133^{\circ} 38^{\prime} \mathrm{W}$

Summary: Prospect known since about 1900 and explored by 3 shafts, several crosscuts from them, and 2 adits. Country rock is slate and chloritic schist (Buddington) or phyllite and muscovitequartz-feldspar schist (USBM in Brew and others). Sulfides and secondary minerals in quartz stringers and mineralized schist (Buddington) or in small massive lenses parallel to foliation and disseminated in country rock (USBM in Brew and others). Sulfldes are mainly pyrite and sphalerite with smaller amounts of galena, chalcopyrite, bornite, chalcocite, covellite, tetrahedrite, and pyrrhotite; also traces of malachite and native silver. Deposits very irregular. Recent analyses and assays of samples Exom adits and surface indicate as much as 159.1 ppm silver, 5,800 ppm copper, $11,000 \mathrm{ppm}$ lead, and 90,000 ppm zinc. Includes references to: Alaska Copper Co.., Sunny Day.

Spencer, 1906 (B 287), P. 44-45 -- In slate-greenstone belt near a diorite intrusive mass more than a mile wlde that altered sedimentary enclosing rocks to quartzite and schist. Country rock Irregularly mineralized zlong schistosity in belt a few humdred feet long and a few hundred feet wide by sulfldes, quaxtz, and calcite. Sulfides include bornite, chalcopyrite, pyrite, sphalerite, and galena; native silver also present. About $200 \mathrm{ft}$. of underground development on one group of claims and a 50-ft. tumel on another.

Wright, 1909 (B 379), p. 72 -- A l1ttle development on Sunny Day, 1908; no mining.

Martin, 1920 (g 712), p. 30 -- Some work by Alaska Copper Co., 1918. Buddington, 1925 (B 773), p. 131-133-- one lode in green chloxitic schist (probably an altered volcanic rock) consists of quartz stringers and mineralized schist and containg pyrite, chalcopyrite, and sphalerite; explored by 3 shafts from which crosscuts were driven to intersect the lode. Reported that veins 8, 2, and $6 \mathrm{ft}$. wide and an 18-in. streak of high-grade ore were encountered. All workings flooded in 1923. Another lode in black slate is about $20 \mathrm{ft}$. wide and consists of many quartz veins with bleached and mineralized muscovite schist leaves and a 10-in.-thick limestone bed with sulfidos. Tunnel $20 \mathrm{ft}$. long in thig lode and a short drift in a 1-1/2-ft. stringer of ore below lode. Minerals in lode include primary pyrtte, sphalerite, borntte, galena, and chalcopyrite, secondary chalcocite and covellite, and little native silver. High silver content invarlably accompanies hlgh copper content. [No data on tenor of deposits.]

Buddington and Chapin, 1929 (B 800), p. 318 -- Example of replacement and impregnation deposit.

p. 323 - Bornite associated with pyrite, sphalexite, and galena in metallized quartz strlngers in greenstone schist and in impregnated schist and partly replaced limestone layers.

p. 327 - small amounts of native silver present. 
(Point Astley) -- Continued

Wedow and others, 1952 (OF 51), p. 60 -- Considered worthy of investigation as a potential source of uranium.

wedow and others, 1953 (C 248), p. 6 -- 10 to $15 \mathrm{ft}$. thick zone in which metallic minerals occur as lenticular replacement veins parallel to schlstosity of country rock. Part of zone 1-2 ft. thick contains 0.006 eU.

p. 10 -- Lenticular replacement veins parallel to schistosity of paleozoic(?) chlorite-sericite schist are made up of pyrite, sphalerite, bornite, phyyhotite, galena, and covellite(2) in a quartzcarbonate gangue; maximun radioactivity of $0.006 \mathrm{eU}$.

Rouston and others, 1958 (B 998-A), p. 25, 27 -- Lenticular replacement veing strike $\mathrm{N} 0^{\circ}-30^{\circ} \mathrm{W}$ and $\mathrm{d} d \mathrm{p}$ about $70^{\circ} \mathrm{E}$ parallel to schistosity of the country rock. Veins contain pyrite, sphalerite, borndte, pyrrhotite, galena, chalcopyrite, malachite, covellite, and chalcocite in a gangue of quartz, carbonate, and impregnated schist; traces of native silver reported. Sample of a 2-ft. interval in a minerallzed zone 10-15 ft. wide contained $0.006 \%$ eU; no uranium minerals identified.

Herreid, 1962, p. 56-58 -- Much of data from older reports or on regional geology. Deposits are near contact between green chloritic phyllito and black slaty phyllite. Velns and sulfides are pretectonic.

samples from adits assayed $0.078-0.958 \mathrm{Cu}, 0.118-0.27 \% \mathrm{~Pb}, 0.08 \%-$ $3.36 \% \mathrm{zn}$, and $1.23 \mathrm{oz}$. Ag a ton.

Race, 1962, p. 68-71 -- Has been prospected for gold, lead, and zinc by 2 tunnels and 2 shafts. Development is at high-tide level, so shafts are Elooded. Soil-sample data show no more than $100 \mathrm{ppm} \mathrm{Cu}, 17 \mathrm{ppm}$ Po, and 250 ppm $2 n$.

Mackevett and Blake, 1964 (B 1208-E), p. E4 -- References to older work.

Berg and Cobb, 1967 (B 1246), p. 190 -. Lenticular veins parallel to fol1ation of slate and schist consist of pyrite, sphalerite, bornite, pyrshotite, galena, chalcopyxite, malachite, covellite, chalcocite, and native silver in gangue of quartz, calcite, and schist fragments. Explored, mainly in about 1900 and between 1916 and 1920, by 3 shafts, about 230 ft. of crosscuts, and several adits. Rumored to have boen worked for some silver ore. Assay data same as in Herreid, 1962, p. 57.

Eakins, 1975 (GR 44), p. 34, 37 -- has been underground exploration. Reference to Houston and others, 1958 (B 998-A), p. 25.

Brew and others, 1977 (OF 77-649), p. 6-7 -m Deposit has long been known, but not thoroughly explored; extremely irregular and lateral and vertlcal continuity of mineralized zones are not known.

p. 127 -- Disseminated grains and lenses of sphalerite, chalcopyrite, galena, and traces of bornite and tetrahedrite generally follow foliation of muscovite-quartz-feldspar schists; distributed erratically over several acres. Some early development, but no production.

p. 138-142 -- Deposit has been restaked many times. Most work was evidently done before 1925. 3 shafts and some crosscuts (all now flooded or covered by landslide) and 2 short adits. Mineralization 


\section{(Point Astley) -- Continued}

is disseminated sulfides and massive sulfide lenses no more than a few feet long parallel to foldation of chlorite phyllite and schist. Sulfides mainly pyrite and sphalerite with lesser amounts of galena and occasional chalcopyrite; also some bornite, chalcocite, covellite, and digenite. 2 zones of mineralization about $700 \mathrm{ft}$. apart. Samples analyzed and sssayed contained as much as $159.1 \mathrm{ppm} \mathrm{Ag}$, 5,800 ppm Cu, 11,000 ppm Pb, and 90,000 ppm $\mathrm{Zn}$.

p. 263-264 -- Prospect has been known since tum of the century: little development. Disseminated pyrite and sphalerite with lesser amounts of galena and copper sulfides in altered muscovite-guartzfeldspar schist. Locally sulfides form lenses less than $0.9 \mathrm{~m}$ ( 3 ft.) long and usually less than $0.3 \mathrm{~m} \mathrm{(l} \mathrm{ft.)} \mathrm{wide.} \mathrm{Mineralization}$ in a broad, irregular zone (or zones) a few hundred meters in strike length. 
(Poxt Houghton)

Petersburg district

MF-425, 100, 18
Copper; Garnet

Sundurn $(8.6,5.5)$

$57^{\circ} 19^{\prime} \mathrm{N}, 133^{\circ} 05^{\prime} \mathrm{W}$

Sumary: Fissure vein from 2 to more than $12 \mathrm{ft}$. thick in shear zone in schlst consists of intergrown pyrrhotite, pyrite, magnetite, chalcopyrite, quartz, garnet, ano amphibole. Grab sample across vein (including both mineralized and barren material) contalned 1.34\% copper and doubtful traces of gold and nickel. Deposit explored by open cuts, several adits, and a 115-ft. drift along the vein. No recoza of any production.

Wright and wright, 1906 (8 284), p. 41 -- Little prospecting; no important ore bodies have been reported.

Buddington, 1925 (B 773), p. 128-130 -- Fissure vein in shear zone between light-colored quartz-feldspar schist and black homblende schist strikes $\mathrm{N} 50^{\circ}-55^{\circ} \mathrm{W}$, dips $70^{\circ}-80^{\circ} \mathrm{W}$, and varies in thickness Erom 2 to more than 12 ft. Explored by pits, several adits (longest $110 \mathrm{Et}$. longl, and a drift that follows the vein for about $115 \mathrm{ft}$. Vein contains pyrrhotite, pyrite, magnetite, and chalcopyrite intergrown with quartz, garnet, and amphibole. Asgay of arab sample showed $1.348 \mathrm{Cr}$, doubtful traces of $\mathrm{Ru}$ and $\mathrm{Ni}$, and no Pt. Kaufman, 1958 (IC 7844), p. 11 -- Garnet reportod.

Berg and Cobb, 1967 (B 1246), p. 191 -- Fissure vein 2-12 ft. thick in a shear zone between guartz-feldspar schist and hornblende schist consists of intergrow pyrrhotite, pyrite, magretite, chalcopyrite, cuartz, garnet, and amphibole. Explored by open cuts, 2 short adits, and a tunnel leading to a 115-ft. drift. Sample across vein (including both mineralized and barren material) contained $1.34 \% \mathrm{Cu}$ and possible traces of gold and nickel. 
Portland

Petersburg district

$\mathrm{ME}-425$, loc. 8
Copper, cold, Lead, silver, zinc

Sumỏum $(6.0,12.6)$

$57^{\circ} 41^{\prime} \mathrm{N}, 133^{\circ} 21^{\prime} \mathrm{W}$

Sumary: Disseminated sulfides and quartz-calcite stringers along foliation of iron-stained silicified mica schist and phyllite near Coast kange batholith. Explored by 3 adits (total length 305 ft. $)$ probably between 1890 and 1910. Sulfides present are pyrite and pyrrhotite and smaller amounts of galena, sphalerite, and chalcopyrita. Old assays of $\$ 0.50-\$ 3$ a ton reported. Richest samples collected recently contained 0.10 ppm gold, 10 ppm sllver, 930 ppm copper, 1,800 ppm lead, and 3,400 ppm zinc.

spencer, 2906 (B 287), P. 45 - clalms on mineralized rock in schist belt adjacent to Coast Range diorlte. Disseminated sulfides and stringers of guartz and calcite in openlngs along schistosity in zone nearly $1,000 \mathrm{ft}$. wide and traceable for a mile or more. Gold-bearing pyrite, galena, and sphalerite reported to assay $\$ 0.50$ to $\$ 3$ a ton. Crosscut $180 \mathrm{ft}$. long and a few open cuts constitute the development. Wright and Wright, 1906 (B 284), p-41 -- Assessment work only, 1905. Herreid, 1962, p. 48 -- In 1962 investigation "The Portland Group.... turned out to be devoid of economic metal values."

p. 58-59 -- quotation from spencer, 3906 (B 287), p. 45 . Two adits (total length about $300 \mathrm{ft.}$. ) in phyllite with quartz veins and layers; only vislble mineralization is "sporadic cubes and a few seams of pyrite." Assays of chip samples showed no more than traces of $\mathrm{Au}$ and $\mathrm{Ag}, 0.408 \mathrm{Cu}, 0.23 \mathrm{gb}$, and $0.528 \mathrm{zm}$. quartz is pretectonic.

Race, 1962, p. 68-71 - Evidently was an old gold prospect. Soil sample (probably contaminated) containod $3 \mathrm{ppm} \mathrm{Cu}, 185 \mathrm{ppm} \mathrm{pb}$, and 3,000 ppm $\mathrm{Zn}$.

Berg and Cobb, 1967 (B 1246), p. I90 -- Data from Spencer, 1906 (B 287) and Herreid, 1962, p. 58-59 [not specifically cited].

Brew and others, 1977 (OF 77-649), p- 215-217 -- References to Spencer, 1906 (B 287) and work by Hexxeid and Race reported in Herreid, 1962, and Race, 1962. Claims located in 1889 and relocated in 1897.365 ft. of workings in 3 adits; probably between 1890 and 1910; accoss iron-stained silicified muscovite schist and phyllite that contain many quartz stringers and lenses parallel to schistosity. Pyrite, pyr rhotite, and traces of galena, sphalerite, and chalcopyrite as disseminations and occasional thin stringers parallel to foliation. Richest sample collected ( $8 \mathrm{ft}$. long from a crosscut) contained 0.10 ppm Au, $10 \mathrm{ppm} \mathrm{Ag,} 930 \mathrm{ppm} \mathrm{Cu}, 1,800 \mathrm{ppm} \mathrm{Pb}$, and 3,400 ppm $\mathrm{zn}$. 
(Powers $\mathrm{Cx}$.)

Petersburg district

MF-425, 10c. 24
Copper, Gold

Sundum $(4.6,13.45)$

$57^{\circ} 46^{\prime} \mathrm{N}, 133^{\circ} 30^{\prime} \mathrm{W}$

Sunnary: Placer gold discovered in 1869, some mining, 1870-71. Anount recovered not known; that from powers $C x$. and windhar Bay area in 1870-71 was nearly 2,000 oz.: most probably from slate Cr. Pan concentrates contain gold, pyrchotite, and chalcopyrite, all probably derlved from (sumdum) copper-zinc deposit; in-place tenor of gravels that were sampled is no more than 0.0031 oz. per cubic yard.

Spencer, 1906 (B 287), p. 2 -- Gold discovered, 1869.

p. 45 - mas been a little small-scale mining; many clains were located, but few were held.

Kaufman, 1958 (IC 7844), p. 7 -- Rlacer gold discovered in 1869, During next 2 years gold worth about $\$ 40,000$ was recovered from powers $C x$. and the Windham Bay area.

Cobb, 1973 (B 1374), p. 103-104 - Placer mining in whtham Bay area and Powers $\mathrm{Cr}$. was carried on sporadically from as early as 3888 until as recently as 1950; amount produced was undoubtedly small lmost was from tributaries of windham Bay].

Brew and others, 1977 (OF 77-649), p. 130 -- Reference to spencer, I906 ( 8 287); nearly 2,000 oz. placer gold produced in 1870-71 from powers $C r$. and Windham Bay araa (probably spruce $C r$. ); amount from Powers $\mathrm{Cr}$. cannot be determined.

p. 224-225 -- Same data as on p. 130. Most recent placer claim was recorded in 1911. Pan concentrates contalned gold, chalcopyrite, and pyrrhotite; source may be sumdum copper-zinc deposit. Mssays of samples indicated in-place tenors of nil to $0.0031 \mathrm{oz}$. gold per cubic yard.

p. 267 -- Reference to Spencer, 1906 (B 287). 
(Sawyer Glacier)

Juneau district
Gold

Sumäum (8.75, 16.5)

$57^{\circ} 56^{\prime} \mathrm{N}, 133^{\circ} 04^{\prime} \mathrm{W}$

Submary: Channel sample across $30 \mathrm{ft}$. of stained gnelss contained 0.10 ppin gold.

Brew and others, 1977 (OF 77-649), p. 246 (10c. 510) -- Samples contained 10-30 ppm Mo. A 30 ft.channel sample across stained gneiss contained 0.10 gpm Au. 
(Snettisham)

Juneau district

MF-425, Loc. 2
Copper, Iron, Platinun, Titanium, Vanadium

Sumdum $(2.15,17.3)$

$57^{\circ} 59^{\prime} \mathrm{N}, 133^{\circ} 46^{\prime} \mathrm{W}$

Sumary: Pyroxenite underlies about 390 acres; gxadational contacts with diorite and sharper contacts with phyllite, into which tongues of pyroxentte extend. Tltaniferous magnetite both disseminated and in masses in pyroxenfte; associated with sphene, apatite, epidote, and small amounts of pyrrhotite, chalcopyrite, ilmenite, and spinel. Extensively diamond drilled by USBM. Composite core sample contained $18.98 \mathrm{Fe}, 2.6 \% \mathrm{~T} 1 \mathrm{O}_{2}, 0.29 \% \mathrm{~S}, 0.328 \mathrm{P}$, and $0.05 \% \mathrm{v}$. Beneficiation tests resulted in a product containing $648 \mathrm{Fe}, 3.5 \% \mathrm{TiO}_{2}, 0.38 \mathrm{~V}, 0.48 \mathrm{~S}$, and less than $0.01 \%$ P. Body estimated to contain 500,000 tons of material with 10\%-20\% $\mathrm{Fe}$, more than $2 \% \mathrm{TiO}_{2}, 0.7 \% \mathrm{~V}_{2} \mathrm{O}_{5}$, and $0.0027 \mathrm{oz}$. per ton of platinum-group metals. See also crystal.

Buddington, 1925 (B 773), p. 133-134 -- Snettisham Peninsula is made up mainly of diorite and hornblendite. Much accessory magnetite in the hornblendite; pegmatitic variants in places are all magnetite. One vein of practically solid titaniferous magnetite about $6 \mathrm{ft}$. wide was the source of a test shipment of 4 or 5 tons reported to contain 4 or $5 \% \mathrm{~T}$. A polished section of magnetite ore consistad of granular magnetite with accessory ilmenite and silicates; ilmenite in grains 0.2-1 mm in diameter, as very small grains along boundaries of magnetite grains (diameter 0.5-1.5 mu), and as microscopic lamellae along parting planes of magnetite. Ilmenite made up about 8 s of the ore. Country rock adjacent to magnetite vein contains about $14 \%$ magnetite. Magnetic disturbance covers an area of about $20 \mathrm{sq}$ - mi. Buddington and Chapin, 1929 (B 800), p. 352 -- Data from above.

Twenhofel, 1953 (C 252), p. 10 -- Titaniferous magnetite concentration in basic igneous or metamorphic rocks.

Thorne and Wells, 1956 (RI 5195) -- References to Buddington, 1925 (B 773), and Buddington and Chapin, 1929 (B 800). Pyroxenite intrusive body underlies an area of about 390 acres with local relief of 1,000 ft. Pycoxenite has gradational contacts whth diorite and sharper concacts with phylilte, into which tongues of pyroxenite extend. Titaniferous mgnetite is associated with sphene, apatite, epidote, and small amounts of pyrrhotite, chalcopyrite, ilmenite, and spinel. Most of this report is detalls of a magnetic survey, a diamond-drilling program (more than 6,500 ft. of holes), and beneficiation tests. A composite core semple contatned $18.98 \mathrm{Fe}, 2.68 \mathrm{TiO}_{2}, 0.29 \% 5,0.32$ 8 , and $0.05 \% \mathrm{~V}$. Magnetic-separation beneflciation resulted in recovering $61 \%-62$ of total ixon in the walls in a concentrate containing $648 \mathrm{Fe}, 3.58 \mathrm{TiO}_{2}, 0.38 \mathrm{~V}, 0.48 \mathrm{~S}$, and less than $0.018 \mathrm{P}$. $S$ content could be lowered to 0.07 percent by sintering.

Kaufman, 1958 (IC 7844), p. Il - Reference to Thome and Wells, 1956 (RI 5195). 
(Srettisham) -- Continued

Carr and Dutton, 1959 (B 1082-C), p. 81 -- Iron deposits underlie area of about $8,000 \times 2,000 \mathrm{ft}$. Average crude ore contains about $128 \mathrm{mag}$ netite iron; concentration to about 208 original volume required for assay of $60 \%$ iron.

p. 102 -- Reference to Thome and wells, 1956 (RI 5195), p. 1.

Mackevett and Blake, 1964 (B 1108-E\}, P. E4 -- Reference to Thome and Wells, 1956 (RI 5195).

Noe I, 1967, p. 64 -- Reference to Thorne and Wells, 1956 (RI 5195).

Deposit is estimated to contain 500 million tons of material with 108-20 $\mathrm{Fe}$ and over $28 \mathrm{TiO}_{2}$.

Berg and Cobb, 1967 (B 1246), p. 164 -- Data Erom Thorne and wells, 1956

(RI 5195) [not specifically cited].

Page and others, 1973 (P 820), P. 541 - Table shows 4.55 million troy ounces of identified resources of platinum-group metals. Text states resource as 500 million tons of titaniferous magnetite with an average of $0.0027 \mathrm{oz}$. per ton platinum metals plus an unspecified part of 3.5 billion tons of titanlferous magnet1te with the same plat inum-metal content. Source of data not given.

Fischer, 1975 (P 926-B), p. 85 -- Table shows 450 million tons of "ore" containing $198 \mathrm{Fe}, 2.68 \mathrm{TiO}_{2}$, and $0.098 \mathrm{~V}_{2} \mathrm{O}_{5}$; concentrate containing $64 \mathrm{Fe}, 3.5 \% \mathrm{TLO}_{2}$, and $0.78 \mathrm{~V}_{2} \mathrm{O}_{5}$. Total vanadium resource is shown as 225,000 tons of $\mathrm{V}$.

Brew and others, 1977 (OF 77-649), p. 128 -- Magnetite-rich zoned ultramatic body.

p. $165 \rightarrow$ Reference to Thorne and Wells, 1956 (RI 5195). Magnetic anomaly is 2154 gamenas. 
Sulphide

Petersburg district
Copper, Gold, Lread, Silver, zinc

Sumdun $(6.85,10.75)$

$57^{\circ} 37^{\prime} \mathrm{N}, 133^{\circ} 16^{\prime} \mathrm{W}$

Sumary: poorly defined bands of massive sulfides (incluaing galena, sphalerite, and chalcopyrite) parallel to banding in stall folds in gmeiss and quartzite in zone 5-15 ft. wide and about $830 \mathrm{ft}$. long. Gold (as much as 0.3 ppm by fire assay) and silver (as much as 43.9 ppm by fire assay) in samples. Only development is 4 shallow open cuts.

Brew and others, 1977 (OF 77-649), p. 219-221 -- Staked and restaked several times since 1928. Exploration consists of 4 shallow open cuts that define a mineralized zone 5-15 ft. wide and about $830 \mathrm{ft}$. long roughly payallel to foliation in gnelss and quartzite. poorly defined bands of massive sphalerite, galena, chalcopyrite, pyrrhotite, arsenopyrite, and marcasite follow selective horizons in minor folds and have been metamorphosed. Analyses of channel samples indicated as much as $30 \mathrm{ppm} \mathrm{Ag,} 0.15 \mathrm{ppm} A \mathrm{Au}, 2,500 \mathrm{ppm} \mathrm{Cu,} \mathrm{13,000} \mathrm{ppm}$ $\mathrm{Pb}$, and 19,000 ppm $\mathrm{Zn}$. Flre assays showed as much as $0.3 \mathrm{ppm} \mathrm{Au}$ and $43.9 \mathrm{ppm} \mathrm{Ag}$. 
(Sumâum)

Petersburg district

MF-425, 20cs, 5, 6
Copper, Lead, Silver, Zinc

Sumdum $(5.05-5.2,23.6-13.9)$

$57^{\circ} 47^{\prime}-57^{\circ} 48^{\prime} \mathrm{N}, 133^{\circ} 27^{\prime} \mathrm{W}$

Summary: Discovered in 1958 and diamond drilled and trenched in 1959. country rock is mainly interlayered 1 ight and dark gneiss sevexal thousand feet west of Coast range batholith. Deposits are minexalized zones $1-50 \mathrm{ft}$. wide along crest and flanks of a large isoclinal fold; made up of disseminated gxains and lenses of pyrrhotite, pyrite, chalcopyrite, sphalerite, bornite, chalcocite, malachite, azurite, galona, and secondary lxon minerals; some zones are brecciated fault zones and disseminated in favorable host rocks. Before regional metamorphism deposits wexe probably volcanogenic or possibly symqenetic. Assuming the deposits are continuous beneath sumdum Glaciex, extend to a depth of 1,000 ft. and have an average width of $31.4 \mathrm{ft} .$, they contain about 26,700,000 tons of material with avexage content of 0.57 z copper, 0.378 zinc, and 0.3 oz. silver a ton.

Race, 1962, p. 68-69 - Has been drilled and mapped by a mining company. "Their report is still confldentlal, but it is understood that this deposit is similar to the Jingle-Jangle [(Tracy Arm)] but somewhat largar and of lower grade." Deposit not discemable from soil samples taken near sea level and a mile from the beach.

U.5. Geological Survey, 1962 (p 450-A), p. A54 -- Sumdum copper-zinc deposit is on numerous sulfide replacements and disseminations localized in gneigs and schist, and less extensively in fault zones. In order of general decrease in abundance the sulfides are pyxite, pyrrhotite, sphalerite, chalcopyrite, and bornite.

MacKevett and Blake, 1964 (B 1108-E) -- Discovered in 1958 and explored (dlamond drilling and trenching) by a private company in 1959. Prospect blsected by Sumdum Glaciex; bedrock recently doglaciated and in many places covered by ice and snow. Country rock of prospect (several thousand feet west of coast Range batholith) is mainly interlayered light and dark gneiss bounded on the east by calc-silicate rocks separated from diorite of the coast Range batholith by a fault nearly paraliel to banding of metamorphic rocks, bounded on west by schist. Metamorphic racks isoclinally folded and overtumed to sW; folds plunge gently to SE. Focks regionally metamorphosed; some contact metamorphism near batholith. Rocks at prospect cut by several NW-striking and a few NE-striking faults and by a fow dikes and silis of lamprophyre and pegmatite and by apopkyses of dioxite. Mineralized zones are 1 to $50 \mathrm{ft}$. thick and localized along minor folds, in brecciated fault zones, and disseminated in favorable host rocks; formed by replacement and open-space filling. Sulfides are dominantly pyrite and pyrrhotite, with sphalerite and chalcopyrite and minox amounts of bormite, chalcocite, malachite, azurite, galena, and secondary iron minerals. Mlneralized zones exposed for only a few hundred feet along strike because of snow and glacial cover; diamond 
(Sumdum) -- Continued

Arilling demonstrated that at least two are continuous for several thousand feet along strike. Assays of samples from surface cuts and diamond-drill cores generally ran about $0.5 \%-1 \% \mathrm{Cu}$, slightly less than $0.5 \% \mathrm{Zn}$, and about $0.25 \mathrm{oz}$. silver ton.

Noel, 1966, p. 63 -- Reference to Mackevett and Blake, 1964 (B 1108-E). Berg and Cobb, 1967 (B 1246), p. 189-190 -- Data sumarized from Mackevett and Blake, 1964 (B 1108-E) (not specifically cited].

Eakins, 1975 (GR 44), p. 34 -- Reference to Mackevett and Blake, 1964 (B 1108-E).

Brew and others, 1977 (OF 77-649), p. 4 -- Prospect is estimated to contain 24.2 million metric tons $(26.7$ million tons) of inferred ore, averaging $0.57 \mathrm{cu}, 0.37 \mathrm{zn}$, and $10.3 \mathrm{~g} /$ metric ton $(0.30 \mathrm{oz} /$ ton $)$ silver.

P. 128-129 -- Pyrrhotite, pyrite, chalcopyrite, and sphalerite occur as disseminated grains and as lenses parallel to foliation of metamorphlc rocks; these minerals developed metamorphic texture and structure coincident with development of foliation.

p. 205-212 -- Discovered, 1958. Data about the same as in Mackevett and Blake, 1964 (B 1108-E). Inferred resource of exposed part of prospect is $26,700,000$ tons with an average width of $31.4 \mathrm{ft}$. and average assay content of $0.578 \mathrm{cu}, 0.37 \mathrm{zn}$, and $0.30 \mathrm{oz}$. silver per ton.

p. 258-259 - Probably syngenetic or (more likely) volcanogenic deposit before metamorphism. Deposit consists of massive and disseminated sulfides in 2 steeply dipping paraliel zones $1-50 \mathrm{ft}$. thick and roughly parallel to foliation of country rock; along crest and flanks of an isoclinal fold. If continuous beneath sundum Glacier have strike length of about $10,000 \mathrm{ft}$. Assuming 9,000-ft. Length, 31.4-ft. width, and depth of 1,000 ft., deposit is calculated to contain resources listed on p. 212.

p. 261 -- Would have been found in Tracy AzTo-Fords Terror project if it had not already been alscovered. Not discemible from streamsediment data. 
Sundum (Chief)

Petersburg diatrict

MF-425, loc. 9
Copper, Gold, Lead, Silver, Zinc

Suncium $(5.25,21.35)$

$57^{\circ} 39^{\prime} \mathrm{N}, 133^{\circ} 26^{\prime} \mathrm{W}$

Summary: Produced about 24,000 oz. gold and probably about the same amount of silver from 2 quartz-calcite veins in slate (spencer) of fissile graphitic limestone (USBM in Brew and others). Veins stoped fxom tunnel to surface, distances of 500 and 1,200 Et. Lodes as much as $20 \mathrm{ft}$. thick; gold distribution uneven; in pockets where small veins intersect main veins. Ore ran about 0.4 oz. gold a ton. Free gola accompanied by auriferous pyrite, sphalerite, galena, chalcopyrite, and arsenopyrite.

Beckex, 1898, p. 62-63 -m Minexals present include galena, pyrrhotite, and $z$ incblende.

p. 75 76 - Stringer lead that generally follows contact between green slate and black bituminous slate. Main oxe lens being worked is 5 ft. or lass thick and consists of quartz, galena, sphalerite, pyrite, and arsenopyrite; yichest along footwall; some copper stains. ore runs about $\$ 50$ to $\$ 60$ a ton with about equal quantities of gold and silver. Production in 1896 reported to be nearly $\$ 96,000$ (about 4,645 fine oz. if all had been gold].

Spencer, 1904 (B 225), p. $29 \cdots$ In 1903 had been worked out and abandoned. p. 36 -- Black shales carry veins from which about $\$ 4,50,000$ has been mined (about 21,770 ine oz. if all had been gold).

Wright and Wright, 1905 (8 259), p. 53 -- Operations closed and mining plant to be removed; quartz ledge failed at depth, 1904.

Spencer, 1906 (B 287, p. 4 - Worked out and abandoned as of 1903.

p. 44 -- Two quartz-Eilied Eisgures approximately parallel to trend of slate country rock; extend a few hundred feet horizontally and were mined for depths of several hunared feet. Sumdum chief vein narrows from a surface width of $3 \mathrm{ft}$. to a narrow vein filling at depth of 1,200 ft.; Bald Eagle veln widens from width of $2 \mathrm{ft}$. assaying $\$ 10-\$ 20$ in gold at surface to width of $20 \mathrm{ft}$. assaying no more than $\$ 1-\$ 2$ in gold at depth of $500 \mathrm{ft}$. Gold in pockets where small veins intergect main veins. Ore is free-milling gold and auriferous pyrite with a little galena and sphalerite in quartz and calcite gangue. Tunnel 3,500 ft. Long undercuts Bald Eagle vein at depth of $500 \mathrm{ft}$. and sumdum chief vein at depth of $1,200 \mathrm{ft} . ;$ both veins stoped out from tunnel to surface, material below tunnel too low grade to mine. Mining ended in late 1903. Ore milled yielded average of $\$ 8$ an in free gold and concentrates containing $\$ 60$ in gold and $20 \mathrm{oz}$. or thore silver a ton. Total production worth nearly $\$ 500,000$ [about 24,190 fine or. if all had been gold].

Wright and wright, 1906 (B 284), p. 40-41-- No mining, 1905; ran out of ore.

Wright, 1907 (B 314), p. 58 - No work, 1906. Wright, 1908 (B 345), p. $90--$ No work, 1907. Buddington and Chapin, 1929 (B 800), p. 317 - Bald Eagle is an example of a Elssure vein. 
Sumdum (Chief) -- Continued

Hexreid, 1962, p. 48 - Not visited in 1962 investigation; copper-zinc sulfide ore body.

Race, 1962, p. 68 -- Produced about $\$ 500,000$ worth of gold before deposit was exhausted.

Berg and Cobb, 1967 (B 1246), p. 190 -- Produced nearly $\$ 500,000$ in gold and silver between about 1896 and 1904 when the ore ran out. Mined From 2 veins by stoping to surface from 3,500-ft. tunnel that intersected veins 500 and $1,200 \mathrm{ft}$. below theiz outcrops. Ore bodies were in black slate and consisted of well-defined quartz-calcite fissure veins carrying fxee gold, auxifexous pyrite, galend, sphalerLte, and arsenopyrite - ore ran about $\$ 8$ a ton.

Koschmann and Bergendahl, 1968 (P 610), p. 20 -- In early days of lode mining was an important mine. Placer gold discoveries in area in 1869.

Eakins, 1975 (GR 44), p. 34 -- Said to have produced about $\$ 50,000$ [should be $\$ 500,000$ ] in gold before closing in 2904 .

Bxew and others, 1977 (OF 77-649), p. 3 -- About 24,000 oz. gold and probably a similax guantity of silvex produced.

p. 6-7 -- Gold-bearing quartz velns in shaly limestone. Mined out before 1905; ore ran about 0.4 oz. gold a ton.

p. 107 -- Silver accompanies gola.

p. 129-130 -- Geochemically and visually obscure; deposit probably would not have been discovered by Tracy Arm-Fords Terror project. Roference to Spencer, 1906 (B 287).

p. 176-182 -- Historical data and description of area- Only accessible working is a stope on Sumdun Chief vein. Shaft pillar remains in stope; quartz vein $1 \mathrm{ft}$. thick; in fissile graphitic limestone; contains pyrite, sphalerite, galena, chalcopyrite, and disseminated fine grains of gold. Chip sample across vein contained $0.88 \mathrm{oz}$. gold and 0.76 oz-silver a ton, $940 \mathrm{ppm} \mathrm{Cu}, 1,900 \mathrm{ppm} \mathrm{Pb}$, and 3.100 ppra $2 n$.

p. 263 -- Summary of some of above.

p. 265 -- Veins not detected by geochemical sampling. 
Sunuaxy: Old reports mention claims and assessment work on one or more occurrences of gold- and galena-bearing quartz in schist. Includes reference to cook.

Spencer, 1906 (B 287), p. $47_{\text {- }}$ - issessment work on prospect in schist belt near a lake $3 \mathrm{mi}$. east [text says west] of South Axm of port Snettisham. Aurifezous guartz with considerable galena.

Wright and wright, 1906 (B 284), p. 41 -- Cook group is on galena deposit in schist belt.

Berg and Cobb, 1967 (B 1246), p. 155, 158 - Auriferous quartz in schist also carries considerable galena.

Brew and others, 1977 (OF 77 649), p. 188 189 - Garbled references to Spencer, 1906 (B 287) and [probably] Wright and Wright, 1906 (B 284). Prospect could not be found during Tracy Axm-Eords Terror Wildexness study Area investigations. Records indicate that in 1902 cook recorded 3 claims near sweetheart lake. 
Juneau district

Summary: Sulfides (chalcopyrite, pyrite, sphalerite, galena) disseminated and in thin layers in bands of schist in a lirear depression. Best zone of those discovered and sampled contains for a length of $147 \mathrm{ft}$. and an average width of $5.5 \mathrm{ft}$. for every $100 \mathrm{ft}$. of depth about 7,300 tons of material with an average grade of $0.23 \mathrm{oz}$. gold and $0.31 \mathrm{oz}$. silver per ton and 0.78 copper. No secondary enrichment in oxidized surface capping. No development.

Brew and others, 1977 (OF 77-649), p. 4 -- A 147-ft.-long portion of mineralized zone is estimated to contain 7,300 tons of inferred ore per hundred feet of depth that average $0.23 \mathrm{oz}$. gold per ton and $0.7 \%$ copper.

p. 128 -- In Sumdum Glacier mineral belt. Parallels foliation of the metamorphic rocks. Among components, gold and copper dominate. p. 192-199 -- Mineralized zone of iron-stained schist and gneiss follows trend of chlorite schist country rock for at least 2,000 ft. in a linear depression that extends for $5.5 \mathrm{mi}$. with a vertical range of 3,000 ft. Sulfides are both disseminated and in thin layers; include chalcopyrite and pyrite with occasional sphalerite and rare galena. Most important zone found is cataclastic quartz-rich gneiss 5-6 ft. thick capped with intense red-orange stain with no secondary sulfide enrichment or residual gold concentration. Samples across zone contained $0.114-0.577 \mathrm{oz}$. gold per ton, $0.01-0.65 \mathrm{oz}$. silver per ton, and 0.21-0.93 percent copper for the best 147-ft.-long section. Estimated resource per $100 \mathrm{ft}$. of depth for zone $147 \mathrm{ft}$. long and 5.5 ft. wide is about 7,300 tons of material with average grade of $0.23 \mathrm{oz}$. gold and $0.31 \mathrm{oz}$. silver per ton and $0.7 \mathrm{~s}$ copper. zone may extend to north; no outcrops. Samples from the rest of the altered zone consistently contained as much as $0.9 \mathrm{ppm} \mathrm{Au}, 20.9 \mathrm{ppm} \mathrm{Ag}$, and $28 \mathrm{Cu}$. Parallel zones seem to carry less gold and silver and some Zn. Deposits may be of sedimentary origin.

p. 258 -- Deposit warrants further investigation.

p. 260-261 -- Repetition of resource data. Deposit not reflected in stream-sediment-sampling data. 
(Tracy Arm)

Petersburg district

MF-425, 10C. 4
Copper, Gold, Lead, Sllver, zinc

Sundum $(4.0,15.9)$

$57^{\circ} 54^{\prime} \mathrm{N}, 133^{\circ} 34^{\prime} \mathrm{W}$

Sumary: A nearly vertical shear zone containing banded pyrrhotite, sphalerite, chalcopyrite, and a little galena parallel to the banding in hornblende gneiss strikes $\mathrm{N} 20^{\circ}-30^{\circ} \mathrm{W}$; exposed in 22 open cuts and 16-ft. shaft over a horizontal distance of 1,150 $\mathrm{ft}$. and vertical distance of $110 \mathrm{ft}$. with a width of $\mathrm{l}-10 \mathrm{ft}$. Large quartz diorite sill nearby; metamorphic rocks cut by quartz diorite and mafic dikes. Geochemical sampling indicates that mineralized zone may extend several hundred feet farther south than inajcated by trenching. Resource estimate Eor what seems to be the richest part of the zone is 187,000 tons of materlal averaging 3.428 zinc, $2.42 \%$ copper, 0.43 oz. silver a ton, and $0.008 \mathrm{oz}$. gold a ton, assuming a length of $850 \mathrm{ft.}, \mathrm{a}$ depth of half the strike length, and a mining width of $5.2 \mathrm{ft}$. Channel samples contained as much as $12.0 \% \mathrm{Zn}, 5.78 \mathrm{Cu}, 1 \mathrm{ppon}$ $\mathrm{Au}$, and 52.4 ppm Ag. Deposit discovered in 1915 or 1916 and restaked several times since then. No record of any production. Includes references to: Jingle-Jangle, Neglected Prize.

Chapin, 1916 ( 8 642), p. 99 -Discovery of a large body of ore carrying $14 \mathrm{z} \mathrm{zh}$ and lesser amounts of gold and copper reported, 1915.

Buddington, 1925 (B 773), P. 130-131 -- Copper prospect is a quartz-sulfide vein parallel to foliation in an aplitic injection gneiss bordered on one side by coast Range diorite and on the other by a sheet of quartz diorite intruded into schist. Walls of vein not sharply definedi veinlets of quartz, sphalerite, pyrite, and chalcopyrite in wall rock. Vein exposed by prospect plts and a shaft $16 \mathrm{ft}$. deep over a length of more than $500 \mathrm{ft}$., reported to be 3-6 ft. wide. Sulfides (pyrrhotite, sphalerite, chalcopyrite, pyxite, and secondary maxcasite) predominate over gangue. Assays reported to run $1.5^{3}$ to $5.6 \% \mathrm{Cu}$ and $4.7 \%$ to $14.64 \mathrm{zn}$.

Buddington and Chapin, 1929 (B 800), p. 362 -- Data from above.

Bain, 1946 (IC 7379), p- 41-42 -- Deposit "estimated to contain 7,000 tons of indicated ore and 140,000 tons of inferred ore with a grade of 4.1 percent zinc, 1.5 percent copper, 0.01 ounce a ton gold, and 1.00 ounce a ton silver." Metallic sulfides ace pyrite, pyrrhotite, marcasite, sphalerite, chalcopyrite, and galena.

Gault and Fellows, 1953 (B 998-A) -- In a belt of metanorphic rocks (schists and phyllites) west of coast Pange batholith; metanorphic rocks intruded by a large quartz diorite sill and numerous quartz diorite and mafic dikes. Deposit is a replacement vein in a shear zone $1-12 \mathrm{ft}$. thick that parallels foliation of metamorphic rocks; partially exposed over a length of $1,140 \mathrm{ft}$. (110 ft. vertically); most of ore confined to southern $830 \mathrm{ft}$. of shear zone; depth not known. Explored with 28 pits, in one of which is a shaft $16 \mathrm{ft}$. deep. ore is sphalerite, pyrxhotite, chalcopyrite, and very small amounts of galend in quartz, mica, and feldspar gangue (gangue more than 50\% of deposit). Same metallic minerals and magnetite sparsely dissemi- 
(Tracy Azm) -- Continued

nated in metamorphic country rocks. Reserves estimated at 40,000 tons of inferred ore per hundred feet of depth with average tenor of 3.28 $\mathrm{zn}, 1.5 \% \mathrm{Cu}, 0.013 \mathrm{oz}$. Au a ton, and $0.75 \mathrm{oz}$. Ag a ton. Estimate based on average width of $4.8 \mathrm{ft}$. over a length of $830 \mathrm{ft}$.

Twenhofel, 1953 (C 252), p. 5 -- Estimated to contain about 125,000 tons of ore containing $4.5^{2}-5.88 \mathrm{zn}$ and $28-3 \mathrm{cu}$. Limits at depth not known .

Kaufman, 1958 (IC 7844), p. 12 - Reference to Gault and Fellows, 1953 (B $998-A$ ).

Herxied, 1962, p. 48 -- Copper-zinc sulflde ore body.

p. 58, 62 -- Reference to Gault and Fellows, 1953 (B 998-A), Sulfides appear to conform to rock (gneiss) structures.

Race, 1962, p. 68-73 -- Reference to Gault and Fellows, 1953 (B 998-A). Deposit not discernible in soil samples taken near sea level; was discernible in samples taken within a few hundred feet of outcrop. Deposit probably extends several hundred feet further south than is Indicated by trenching.

Mackevett and Blake, 1964 (B 1208-E), P. E4, E7, E19, E-23-- References to Gault and Fellows, 1953 (B 998-A).

Berg and Cobb, 1967 (B 2246), p. 189 -- Data summarized from Gault and Fellows, 1953 (B 998-A) (not specifically cited). A little gold and silver reportedly recovered by warly prospectors.

Eakins, 1975 (GR 44), p. 34 - Reference to Berg and Cobb, 1967 (B 1246). Brew and others, 1977 (OF 77-649), D. 4-- Estimated to contain 187,000 tons of inferred ore averaging $3.428 \mathrm{zn}, 1.428 \mathrm{Cu}, 0.43 \mathrm{oz} /$ ton $\mathrm{Ag}$, and $0.008 \mathrm{oz} /$ ton Au.

p. 114 -- Zinc of potential economic value.

p. 128-129 -- Pyrrhotite, pyrite, chalcopyrite, and sphalerite occur as disseninated grains and as lenses parallel to follation of metamorphic rocks. Minerals developed metamorphic texture and stxucture coincident with development of foliation. Deposit goochemically and visually obscure; probably would not have been discovered by Tracy Arm-Fords Terrot praject.

P. 200-203 -- Banded pyrrhotite, sphalerite, and chalcopyrite in a well-defined zone 1-10 ft. wide is parallel to foliation in hornblende-plagioclase to hornblende-blotite gneiss. Exposed in 22 open cuts and a 16-ft. shaft along a strike length of 1,150 Et. (vertical range of $130 \mathrm{ft}$. ); strike is $\mathrm{N} 20^{\circ}-30^{\circ} \mathrm{W}$; mineralized zone nearly vertical. Discovered in 1916 and restaked several times. No record of production. Channel samples contaired $0.028-5.7 \% \mathrm{Cu}$ and $0.02 \%-12.0 \% 2 n$. Fire assays showed as much as $\perp$ ppro $A u$ and 54.2 ppn Ag. Samples from a 300-ft. section along strike assayed 1.428 $\mathrm{Cu}, 3.42 \% \mathrm{mn}, 0.43 \mathrm{oz} /$ ton $\mathrm{Ag}$, and $0.008 \mathrm{oz} /$ ton $\mathrm{Au}$ across an average width of $5.2 \mathrm{ft}$.

p. 258-259 -- Deposit probably was syngenetic or (more likely) volcarogenic before metamorphism. Same resource data as on p. 4 over a length of $850 \mathrm{ft}$. to a depth of half the strike length and for a mining width of 5.2 ft.

p. 261 -- Repetition of data on p. 129 . 
(Windham Bay)

Petersburg aistrict

MF-425, locs. 12-15, 25-29
Copper, Gold, Iron, Lead, Silver, zinc

Surmalum $(6.15-6.75,8.8-10.5)$

$57^{\circ} 30^{\prime}-57^{\circ} 36^{\prime} \mathrm{N}, 133^{\circ} 17^{\prime}-133^{\circ} 20^{\prime} \mathrm{W}$

Sumary: Mineralized zones several hundred feet wide consist of schist and phyllite with guartz veins, some of which parallel and some of which cross foliation; about $7 \mathrm{mi}$. from coast Range batholith; cut by a few smali isolated bodies and premineralization diabase. dikes; one small homblende pyroxenite body. Veins all pinch out in short distances; some are a foot or more thick. Veins carry gold and associated silver, pyrite, pyrrhotite, sphalerite, galena, and chalcopyrite; gold content rarely exceeds $0.25 \mathrm{oz}$. per ton, which here does not constitute minable ore; a few richer isolated pockets. Many underground workings and open cuts excavated at various times since $1890^{\prime} \mathrm{s}$, but probably less than $3,000 \mathrm{oz}$. of gold recovered. Placer gold discovered as early as 1869 and mined sporadically on small scale into 1950 's; amount recovered not known, but undoubtedly smal1; most lor possibly all) from spruce $C r$ - from basing between zones of lode mineralization. Ultramafic body causes magnetic anomaly of 432 gammas; contains some magnetite; chip sample along shore of Windham gay contained 13.2\% Fe; poorly exposed; no exploration. Includes references to: Alaska Peexless (Mining Co.), AlaskaWindham Gold Mining Co., California-Alaska Mining Co., Helvetia Gold Mining Co., Independent Mining Co., Jenny Reed Gold Mining Co., Jensen, Marty (Mines), Rowe, (Shuck R.), (Shuk R.), (Slate Cr.), (spruce Cr.). (Sylva Cr.), (Sylvia Cr.), Windham Bay Gold Mining Co., Windham Chief cold Mining co., Yates.

Brooks, 1904 (8 225), p. 46 - Hydraulic mining, 1903.

Spencer, 1904 (B 225), p. 36-37 -- Placers worked in a small way at various times between 1869 and 1888 . Hydraulic plant installed near mouth of spruce $\mathrm{Cr} ., 1888$; large-scale operations in a basin farther upstream were a failure, although placer gold is present. Has also been sluicing on shuck $R$. Work on lodes genexally discouraging; ixragular guartz veins crosscutting slate contain sulfides and free gold. Mineralized bands of slate contain much disseminated pyrite that carries a little gold, but are too lean to constitute ore.

Wright and Wright, 1905 (B 259), p. 53 -- Developments on many properties, 1904 , but no production; low gold values.

Spencex, 1906 (B 287), p. 38-43 -- Bedrock is slate and schist about $7 \mathrm{mi}$ sW of main mass of coast Range diortte, a few small isolated diorite bodies; several preminexalization diabase dikes generally parallel to trend of slate and schist. At head of bay along spruce $C_{r}$, are 3 zones of stringer leads with many irregular quartz veinlets as much as a foot or more wide and traceable for only short distances. Free gold and sulfides (mainly pyrite with smaller amounts of galena, sphalerite, chalcopyrite, and arsenopyrite) in quartz-calcite-siderite (and rare albite) gangue are irregularly distributed in guartz, country rock, and diabase dikes. Between 1900 
(Wingham Bay) -- Continued

and 1905 several groups of claims along the 3 mineralized zones were explored by 1,500-2,000 ft. of workings and some ore mined, mainly from Red Wing group (Windham Bay Gold Mining Co.); only development in 1905 was by Helvetia Gold Mining Co. Another group of claims (Mildred) on auriferous veinlets in very siliceous slate on north shore of bay was explored by 600-Et. tunnel. Placer mining has been done in the basins of Spruce $C r$. between zones of lode mineralization, at head of spruce $C_{r}$, and on shuck $R$. and its tributary Slate $C x$. ; gravel deposits on another tributary, Sylva Cr., were located.

Wright and wright, 1906 (B 284), p. 41 - In Aug. 1905 only operating company was Helvetia Gold Mining $C o$. Some prospecting near head of Spruce $\mathrm{Cr}$.

Wright, 1907 (B 314), p. 58-59 - work on helvetia property; mill tests not encouraging. Veins on divide at head of bay being prospected, 1906 .

Wright, 1908 (B 345), p. 90 -- Only assessment work and prospecting, 1907.

Wright, 1909 (B 379), P. 72 - A little work, 1908.

Chapin, 1916 (B 642), p. 76 - A property [which one not specified] was sold in 1915; work planned to start in spring of 1916.

Srith, 1917 (BMB 153), p. 20 - Alaska peerless Gold Mining co. opening 3 lode claims by 2 tunnels, 1916.

Martin, 1920 (B 713), p. 30 -n Some work by Alaska Peerless Mining Co.. 1918.

Brooks, 1922 (B 722), g. 36 - In 1919 Alaska Peerless Mining Co. drove $50 \mathrm{ft}$. of adits on old Yellow Jacket claims; total workings are 400 $\mathrm{ft}$. of main tunnel and $300 \mathrm{Et}$. of crosscuts from it and $50 \mathrm{ft}$. of a projected 5,000-ft. adit to undercut the lode $630 \mathrm{ft}$. below workings. In 1920 only assessment work was done.

8xooks, 1923 (B 739), p. 21 -D Development at Alaska Peerless, 1921.

Buddington, 1925 (B 773), p. 125-127-- Lodes are zones of schist and phyllite with many guartz stringexs; contain free gold and sulfides, including pyrite, pyrrhotite, galena, and sphalerite. Most deposits are low grade, but a few rich stringers have been found. A total of about 1,400 feet of underground woxkings on several groups of clains.

Moffit, 1927 (B 792), p. 10 - Mill exected on Peerless property, 1925. Test run not completed at end of season.

p. 15 -- A little placer mining on Shuk R., 1925.

5mith, 1929 (B 797), p. 10-11 -- Jacob Marty Mines acquired some 30 claims and began development; about $1,000 \mathrm{ft}$. of drifts and crosscuts driven, 1926.

Soith, 1930 (B 810), p. 13 -- Development, 1927.

Smith, 1930 (B 813), p. 15 -- Development, 1928.

Smith, 1932 (B 824), p. 16 -- Little new work, 1929.

Srath, 1934 (B 857-A), p. 15 - A little work (mainly prospecting), I932.

Smith, 1934 (B 864-A), p. 17 -- Development work by Alaska Windham Gold Mining Co., 1933.

5mith, 1936 (B 868-A), p. 16 -n Development and preparatory work, 1934.

smith, 1937 (B 880-A), p. 17 - Preparatory work, but no mining, 1935. 
(Winoham Bay) -- Continued

Smith, 1938 (B 897-A), p. 18 - Preparatory work, but no mining, 1936. Smith, 1939 (B 910-A), p. 20 -- preparatory work, but no mining, 1937. Smith, 1942 (B 933-A), p. 32 - Attempts to mine detrital material in some of high-level glacial lakes by draining them through a tunnel seem not to have been successful, 1940.

Kaufman, 1958 (IC 7844), p. 7 -- Placer gold discovered in 1869. In 187071 about $\$ 40,000$ in gold recovered from Windham Bay-Powers $C r$. area.

Berg and cobb, 1967 (B 1246), p. 190-191 - Many auxiferous lodes explored between about 1900 and 1937. Underground workings probably aggregated more than $1,000 \mathrm{ft}$; incomplete records make it impossible to detexmine the number of productive lodes or amount of gold recovered; probably did not exceed 10,000 oz. Lodes in white sericitic and sillceous schist; quartz stringers that contain pyrite, pyrrhotite, galena, sphalerite, arsenopyrite, chalcopyrite, and Exee gold. Pyrite and pyrrhotite also disseminated in schist near the veins. Some deposits reported to be rich; assay datia not available.

Koschmann and Bergendahl, 1968 (p 610), p. 20 -- Placer gold discovered, 1869.

Cobb, 1973 (B 1374), p. 103-104 -- Sporadic placer mining from as early as 1888 to as recently as 1950; from Spruce $\mathrm{Cr}$. and shuck R. and some of its tributaries. Amount recovered not known, but undoubtedly small. Gold dexived from nearby lodes that were too small and too lean for profitable mining.

Eakins, 1975 (GR 44), p. 34 - Reference to Berg and Cobb, 1967 (B 1246). Brew and others, 1977 (of 77-649), p. 6-7 -- Lode mines and prospects mainly along quartz stringexs in broad altered zones; low gold contents that only rarely exceed $0.25 \mathrm{oz}$. per ton.

p. 107 -- Has been production from lodes and placers.

p. 128 -- ultramafic body of incompletely evaluated potential near head of the bay. Magnetic anomaly less prominent than that at snettishan.

p. 130 -- cold produced probably did not exceed 2,700 oz. (total from reglon was about 27,000 oz., of which $908-95 \%$ was from othex places).

p. 143-165 - Several pooxly defined parallel zones of alteration and sulfide mineralization hunareds of feet wide generally follow the follation of stoeply dipping schists and phyllites that strike about $\mathrm{N} 20^{\circ} \mathrm{W}$. Mineralized zones contain small quartz stxingers and lenses, most of which follow schistosity but some of which cross it. crosscutting velns more than 3 in. thick consistently have the highest gold values. All veins pinch out in short distances. Netallic minerals in veins include froe gold (usually in small isolated pockets) and disgeminated pyrite, pyrrhotite, galena, sphalerite, and chalcopyrite; highex gold values often associated with galena. Silver in many assays. Deposits explored by many undexground workings and surface excavations; very little actual mining; sporadic activity since 1890 's. In 1974 all accessible workings were mapped and sampled. Except for a few isolated samples, all mineralized material was too low grade to constitute ore. Snsld hornblende pyroxenite body near head of windham Bay is source of a 432 -ganma 
(Windham Bay) -- Continued

magnetic anomaly; a spaced chip sample taken along shore contained 13.2. $\mathrm{Fe}$ and no significant copper or nickel; material lower grade than that at snettisharn.

p. 169-175 -- Placer gola discovered (probably on spruce $\mathrm{Cr}$.) as early as 1869; sporadic mining until 1950's. Production probably was small; no records. Many of data from spencer, 1906 (B 287). Recent sampling showed low gold contents for Spruce $\mathrm{Cr}$. and Shuck R. and its tributaries.

p. 263-264 -- Mineralization in irregular quartz veins and stringers that both parallel and cut across foliation of low-grade metamorphic rocks. Gold content rarely exceeds $0.25 \mathrm{oz}$. per ton. Both lode and placer production was minor. Lodes too low grade to be mined economically.

p. 267 -- Reference to Spencer, 1906 (B 287). 
Unnamed occurrence

Petergburg district

MF-425, loc. 22

\section{Copper}

Sumdum $(12.25,4.7)$

$57^{\circ} 16^{\prime} \mathrm{N}, 132^{\circ} 43^{\prime} \mathrm{W}$

Sumbary : Epidote-quartz-bornite veinlet.

Clark and others, 1970 (OF 432), p. 5, loc. 91 -- Sample of epidote quartz bornite veinlet. 
Unnamed occurrence

Petersburg district

$M F-425,10 C .21$
Copper

Sundum (11.25, 5.1)

$57^{\circ} 17^{\prime} \mathrm{N}, 132^{\circ} 49^{\prime} \mathrm{W}$

Sumbary: Quartz-epidote-bornite veinlet.

Clark and others, 1970 (OF 432), p. 5, 10c. 78 -- Quartz epidote bornite veinlet. 
Unnamed occurrence

Petersburg district

$M F-425,10 \mathrm{C} .20$
Coppex

Sumdum $(11.8,5.85)$

$57^{\circ} 20^{\prime} \mathrm{N}, 132^{\circ} 45^{\prime} \mathrm{W}$

Sumnary: Bornite in samples from aplite dike, quartz and pegmatite veins, and an epidotized fracture.

Clark and others, 1970 (OF 432), p. 4, loc. 50 -- Bornite in samples from aplite dike, quartz vein, pegmatite vein, and epidotized fracture. 
Unnamed occurrence

Petersburg district

MF-425, 100. 19
Copper

Sundum (11.6, 7.25)

$57^{\circ} 25^{\prime} \mathrm{N}, 132^{\circ} 46^{\prime} \mathrm{W}$

Sumary: Pyrite and chalcopyrite in sample of biotite-quartz gneiss.

Clark and others, 1970 (OF 432), p. 3, 1oc. 21 -- Sample of biotite quartz gneiss contains pyrite and chalcopyrite. 
Unnamed occurrence

Petersburg district
Copper, Lead, Thingsten

Sumaum $(8.2,10.55)$

$37^{\circ} 36^{\prime} \mathrm{N}, 133^{\circ} 07^{\prime} \mathrm{W}$

Sumnary: Traces of galena, pyrrhotite, chalcopyrite, and scheelite.

Brew and others, 1977 (of 77-649), p. 223 -- Float and rock samples contain traces of galena, pyrrhotite, chalcopyrite, and scheelite. stream-sediment sample contained 1,000 ppm W, 2,000 ppm As, and 30 Ppm Be. 
Unnamed occurrence

Juneau district
Coppex, Molybdenum

Sund um $\langle 4.6,16.65\rangle$ $57^{\circ} 57^{\prime} \mathrm{N}, 133^{\circ} 30^{\prime} \mathrm{W}$

Sunnary: Traces of molybdenite and chalcopyrite in quartz pod parallel to foliation in gneiss.

Brew and others, 1977 (OF 77-649), p. 247 (1oc. M-4) -- Chip sample accross a heavily iron-stained guartz pod parallel to foliation of gneiss contained traces of molybdenite and chalcopyrite. Analysis showed $100 \mathrm{ppm} \mathrm{Mo}$ and $200 \mathrm{ppm} \mathrm{Cu}$. 


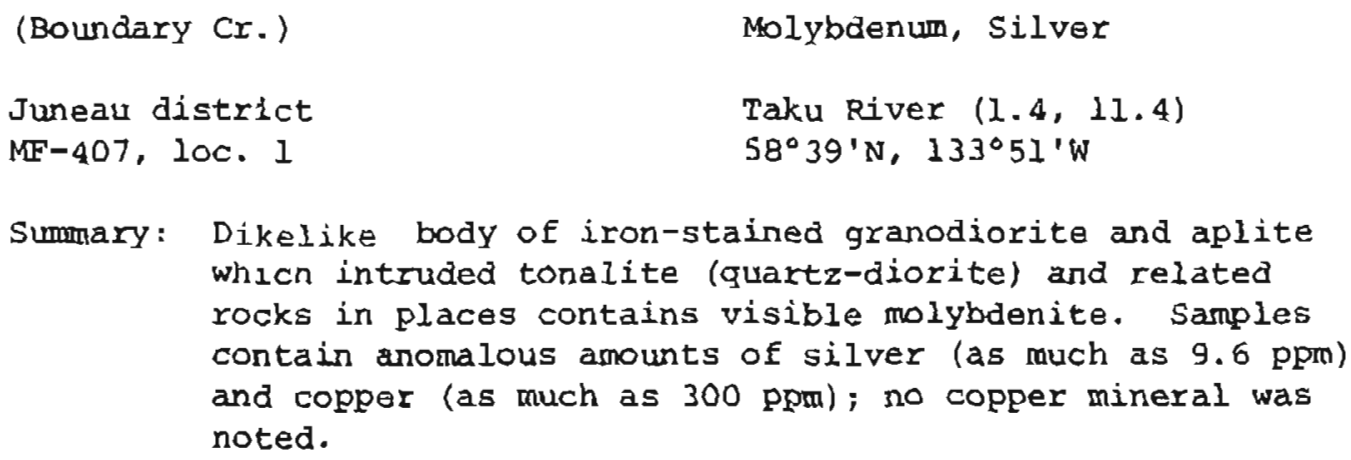

Sumary: Dikelike body of iron-stained granodiorite and aplite whicn intruded tonalite (quartz-diorite) and related rocks in places contains visible molybdenite. Samples contain anomalous amounts of silver (as much as $9.6 \mathrm{ppm}$ ) and copper (as much as $300 \mathrm{ppm}$ ); no copper mineral was noted.

Brew and Ford, 1969 (C 615), p. 12-15-- A Tertiaxy (?) dikelike body of iron-stained granodiorite and aplite is more than $2 \mathrm{~m}$. long and at least 2,000 ft. thick and cuts Cretaceous (?) tonalite and related rocks. Exposed in a recently deglaciated cirque. Parts of the dikelike body contain visible molybdenite; samples contain as much as $9.6 \mathrm{ppm} \mathrm{Ag}$ and anomalous (as much as $300 \mathrm{ppra}$ ) Cu. Data not adequate to appraise economic potential. 
(Limestone Inlet)

Juneau district

MF $-407,200.2$
Copper, Gold, Lead, Zinc

Taku River $(0.3,0.8)$

$58^{\circ} 03^{\prime} \mathrm{N}, 233^{\circ} 58^{\prime} \mathrm{W}$

Sumary: Auriferous quartz veins in granit1c rock which intruded volcanic rocks carry small amounts of galena, sphalerite, chalcopyrite, and pyrite as well as free gold. One vein developed by adits (total length

$440 \mathrm{ft}$.$) on 2$ levels connected by a raise. In 1916 some ore was probably treated in a 5-stamp mill. No data on amount of production. Includes references to: Arizona, Bach, Enterprise, Montana, Williams \& Leak.

Wright, 1908 (B 345), p. 90-- Quartz vein $21 / 2 \mathrm{ft}$. wide in granitic rock exposed over a length of $500 \mathrm{ft}$. on Bach claims, 1907.

Wright, 1909 (B 379), p. 72-- Auriferous quartz veins 3 in. to $9 \mathrm{ft}$. wide in granitic rock that intruded slates and greenstones exposed for several hundred feet by open cuts. Vein on Enterprise clalms averages $5 \mathrm{ft}$. In width and is valuable mainly for free gold; strikes $\mathrm{N}^{\circ} 5^{\circ} \mathrm{E}$ and dips $45^{\circ} \mathrm{NW}$. Parellel vein on Arizona claims averages $1 \mathrm{l} / 2 \mathrm{ft}$. in width and carries fxee gold and small amounts of galena, sphalerite, chalcopyrite, and pyrite. As of 1908 othex veins had been discovered, but not developed, on both properties.

Knopf, 1910 (B 442), P. 139-- Development continued, 1909.

Knope. 1911 (B 480), P. 97-98- Work on Enterpxise in 1910. Deposit. is a sheeted quartz vein in somewhat porphyritic quartz diorite, which intruded a series of volcanic rocks. Vein strikes $\mathrm{N} 20^{\circ} \mathrm{E}$ and dips $45^{\circ} \mathrm{W}, 2-3 \mathrm{ft}$. thick; carries coarse pyrite and galena and free gold; said to dverage $\$ 15$ a ton. Drift is $30 \mathrm{ft}$. long; veln stripped for several hundred feet along outcrop.

Smith, 1917 (BMB 153), g. 24-- Drifts $320 \mathrm{ft}$. and $120^{\prime} \mathrm{ft}$. Iong connected by raise $77 \mathrm{ft}$. long; stopes on both levels. Quartz vein strikes $\mathrm{N} 30^{\circ} \mathrm{E}$, dips $52^{\circ} \mathrm{NW}$, and averages 18 in. thick. Country rock is diorite. Aerlal tram takes ore to 5-stamp mill on beach, 1916. [No data on amount of production.]

Eakin, 2918 (B 662), p. 77-78-- Mill installea; some ore reported to have been milled, 1916.

Berg and Cobb, 1967 (B 1246), p. 155-- quartz veins carrying free gold and small amounts of galena, sphalerite, chalcopyrite, and pyrite. some ore reported to havo been processed in about 1916. 
(Mt. Brundage)

Copper

Juneau district

Taku River $(6.0,4.9)$

$58^{\circ} 17^{\prime} \mathrm{N}, 133^{\circ} 21^{\prime} \mathrm{W}$

Sumary: Traces of chalcopyrite in iron-stained siliceous gneiss.

Brew and others, 2977 (OF 77-649), p. 243-- Samples of iron-stained siliceous gnelss contained no significant metal values, although minor pyrrhotite and traces of chalcopyrite were identified. 
Suncise Canyon

Juneau district

MF-407, 100, 4
Manganese

Taku Rivet $(0.65,1.3)$

$58^{\circ} 05^{\prime} \mathrm{N}, 133^{\circ} 56^{\prime} \mathrm{W}$

Summary: Manganese minerals, mainly rhodochrosite, in a vein or band 1 to $31 / 2$ ft. thick parallel to foliation in phyllite. Beneficiation tests faided to produce a marketable concentrate.

Pittmen, 1958-- Vein or band 1 to $31 / 2$ Et. thick consisting mainly of thodochrosite with smaller amounts of manganite and (or) psilomelane, quartz, and rhodonite are parallel to foliation of the enclosing phyllite. Only development was a few shallow pits and trenches. Discovered in about 1935; 8 claims located then and more staked later. Beneficiation tests failed to produce a marketable concentrate. 
(Taku R.)

Juneau district.
Copper, Gold, Lead, Silver, zinc

Taku River $(3.0,10.0)$ approx. $58^{\circ} 34^{\prime} \mathrm{N}, 133^{\circ} 41^{\prime} \mathrm{W}$ approx.

Summary: Sphalerite, pyrrhotite, pyrite, galena, and chalcopyrite. Low assays for gold and silver. No other data.

Wedow and others, 1952 (OF 51), p. 57-- Considexable sphalexite with pyxrhotite and minor amounts of pyrite, galena, and chalcopyrite reported about a mile fxom the international boundary; low assays for gold and qliver. 
(Whiting R.)

Juneau district

MF-407, 100. 3
Copper, Gold, Lead, Silver, zinc

Taku River $(5.15,0.9)$

$58^{\circ} 03^{\prime} \mathrm{N}, 133^{\circ} 27^{\prime} \mathrm{W}$

Sumary: Quartz veins in dolomite septum (?) or vein pendant (?)

in Coast Range diorite contain arsenopyrite, pyrite,

pyrrhotite, galena, sphalerite, and chalcopyxite. Samples contained as much as 56.9 ppm gold (probably in arsenopyrite) and 1,807.9 pprs silver (probably in galena). Veins complexly faulted. Only one large enough to be of possible economic significance is $4.5 \mathrm{ft}$. wide and was exposed for a lenghthof about $80 \mathrm{ft}$. in an open cut; $75-\mathrm{ft}$.-long crosscut driven to intersect it did not. vein probably faulted aray. Occurrence known since late 1890's; staked and restaked many times. Includes reference to Lost Charlie Ross.

Knopf, 1919 (B 442), p. 139-- Well back in graritic mass of Coast Range. Ore body reported to be $4 \mathrm{l} / 2 \mathrm{ft}$. thick and $100 \mathrm{ft}$. long; quartz carrying galena, arsenopyrite, sphalerite, and pyrite. Assay of "a streak of solid mineral Il inches wide" on footwall gave a return of $\$ 21.60$ [about $1.04 \mathrm{oz}$.$] gold and 50 \mathrm{oz}$. silver a ton and 40\% lead. Tunnel being driven to undercut ore body, 1909.

Chapin, 1916 (8 642), p. 98-99-- Claims said to have been located on silver-bearing galena ore in a quartz vein 6-8 ft. wide.

Buddington, 1925 (B 773), P. 135-136-- Prospect has been known since 1898; located and relocated again and again. Small open cut on veins; tunnel $118 \mathrm{ft}$. long did not reach vein. Quartz fissure vein in belt of coarsely crystalline dolomite (cut by quartz porphyry dikes) in Coast Range diorite; 40 in. wide with band of almost solid sulfides $10 \mathrm{in.} \mathrm{wide} \mathrm{along} \mathrm{footwall.} \mathrm{Sulfides} \mathrm{are} \mathrm{arsenopyrite} \mathrm{(pre-}$ dominant) pyrite, galena, sphalerite, and chalcopyrite. Very high silver assays reported from selected specimens.

Budóington and Chapin, 1929 (B 800), p. 362-- Reference to Buddington, 1925 (B 773), p. 135.

Wedow and others, 1925 (OF 51), p. 57-58-- Data from Buddington, 1925 (B 773), p. 135. [not cited]. Unsubstantiated rumor of uranium find on Whiting $R$.

Kaufman, 1958 ( 1 C 7844), p. 12-- Lead-silver ore body reported.

Berg and Cobb, 1967 (B 1246), p. 255-- Quartz fissure vein in a dolomite inclusion in quartz diorite contains arsenopyrite, pyrite, galena, sphalerite, and chalcopyrite; very high silver assays reported from selected specimens. 
(Whiting $R_{0}$ ) continued

Brew and others, 1977 (OF 77-649), p. 129-- Only previously [before 1972) reported minexalization in coast Range hathn1ithje omnlex [in rracv Arm-Ford's Texror wilderness stifdy areal.

p. 230-233-- Prospect has been knowm since 1896 and was staked and restaked several times. 4.5-ft.-wide sulfide-bearing quartz vein in dolomite exposed for length of about $80 \mathrm{ft}$. in open cut; not found in crosscut driven $75 \mathrm{ft}$. to intresect it; probabiy Eaulted. Sulfides are arsenopyrite, pyrite, pyrchotite, sphalerite, galena, and chalcopyrite; gold values (as much as $56.9 \mathrm{ppm}$ ) probably in arsenopyrite and silver values (as much as $1,807.9$ ppar) in galena. Several smailar veins on prospect; all apparently faulted, 221 too small and too low grade to be of economic significance. 
Synonyms, clatm Names, Operators, and owners

Many mines and prospects have undorgone changes in both their own names and in the names of their operators and owners. All names that eppear in the c1ted references eppear in this sumbry elther in the first section as occurrence names or in this as syoonyms. Descriptions of placer deposits commonly glve little iniormation on the location of individual mines or claims, so the names of all operators. and owners of placer mines and cladms are in this section with a notation to refer to the description of the strean that was mined or prospected. 
Alaska Bond \& Development Co. ... see (Windham Bay)

Alaska Copper (Mining) Co. - see (Point Astley)

Alaska Peerless Gold Minlng Co. -- see (Windham Bay)

Alaska Peerless (Mining Co.) -n see (Windham Bay)

Alaska Snettisham Gold Mining Co. -- see Crystal, Friday

Alaska Ventures -- see (Point Astley)

Alaska-Wladham Gold Mining Co. - see (Windham Bay)

Allce - see (Windham Bay)

Apache -. see (Windham Bay)

Apollo -- see (Point Astley)

Bald Eagle -- see Sumdum Chief

Bas1n queen -- see (Winäham Bay)

Bear Lode -- see (Windham Bay)

Bird - see (Windham Bay)

Blossom - see (Windham Bay)

Boonville -- see (Windham Bay)

Broad - - see (Windham Bay)

Butteroaugh -- see (Tracy Arm)

California-Alaska (Mining Co.) -- see (Windham Bay)

(Chuck R.) -- see (Windham Bry)

Cities Service Minerals corp. -- see (Sumdum)

Cliff - see (Windhan Bay)

Cook - - see (Sweetheart Lake)

Coughlin \& Pekovich -- see (Snettisham)

Croney -- see Sumdum Chilef

Crown - see (Windham Bay)

Deisy Bell -- see Crystal

Doctor - see (W1ndham Bay)

Durer - see (Windham Bay)

Eclipse a see (Sumdum), (Winäham Bay)

Elephant -- see (Sweetheart Ridge)

Ethel - - see (Windham Bey)

Evenzng Star -- see (Windham Bay)

Falrview - see (Windham Bay)

Falls Quartz - see (Windham Bay)

Flossie -- see (Winảbam Bay)

40 Percent - see Sulphide

Fries - see (Windham Bay)

Gertrude -- see (Windham Bay)

Gold Coin -- see (Holkham Bay) 
Golden Gate -- see (Sweetheart Riàge)

Golden River Mining Co. - see (Windham Bay)

Golden Slipper -- see Sumdum Chier

Gold Seal -- see (Holkham Bay)

colo Shaft -- see (Windham Bay)

Great Mine -- see (Winabsm Bay)

Heins -- see Crystal

Helvetie (Gold Minlng Co.) -- see (WIndham Bay)

Iceburg -- see Sulphide

Iâho - see Sulphide

Independent (Gold) Mining Co. -- see (Windham Bay)

Jackson - - see (Windiham Bay)

Jangle - - see (Tracy Arm)

Jenny Reed Cold Mining Co. -- see (Windham Bay)

Jensen -- see (Windhan Bay)

Jingle(-Jangle) -- see (Tracy Arm)

Jongle - - see (Tracy Arm)

Juneau - see (WIndham Bay)

Jungle - see (Tracy ArtD)

Kelth -- see (Windham Bay)

Kloss \& Davis -- see $K$ \& D

Lenark -- see (W1ndham Bay)

Lone Tree -- see Sumaum Chief

Lost Rocker -- see (WIndham Bay)

Lucky Star - see (Point Astley)

Lucky Venture -- see (Polnt Astley)

Lucy -- see (Windham Bay)

Magnetite - see (Snettisham)

Marcona -- see (Snettisham)

Margaruita -- see (Windham Bay)

Marty (Mines) -- see (Winahem Bay)

Mastedon - - see (Sweetheart Ridge)

May - - see (Windham Bay)

Maybe - see sulphide

Milared (Group Mining Co.) -- see (Windharn Bay)

Moneta Porcupine Mines, Ltd. -- see (Sumdum)

Navajo -- see (WIndhar Bay)

Neglected Prize -- see (Tracy Arm)

New Recket - see Sumdum Chief

oceanic (Mining Co.) -- see (Polnt Astley) 


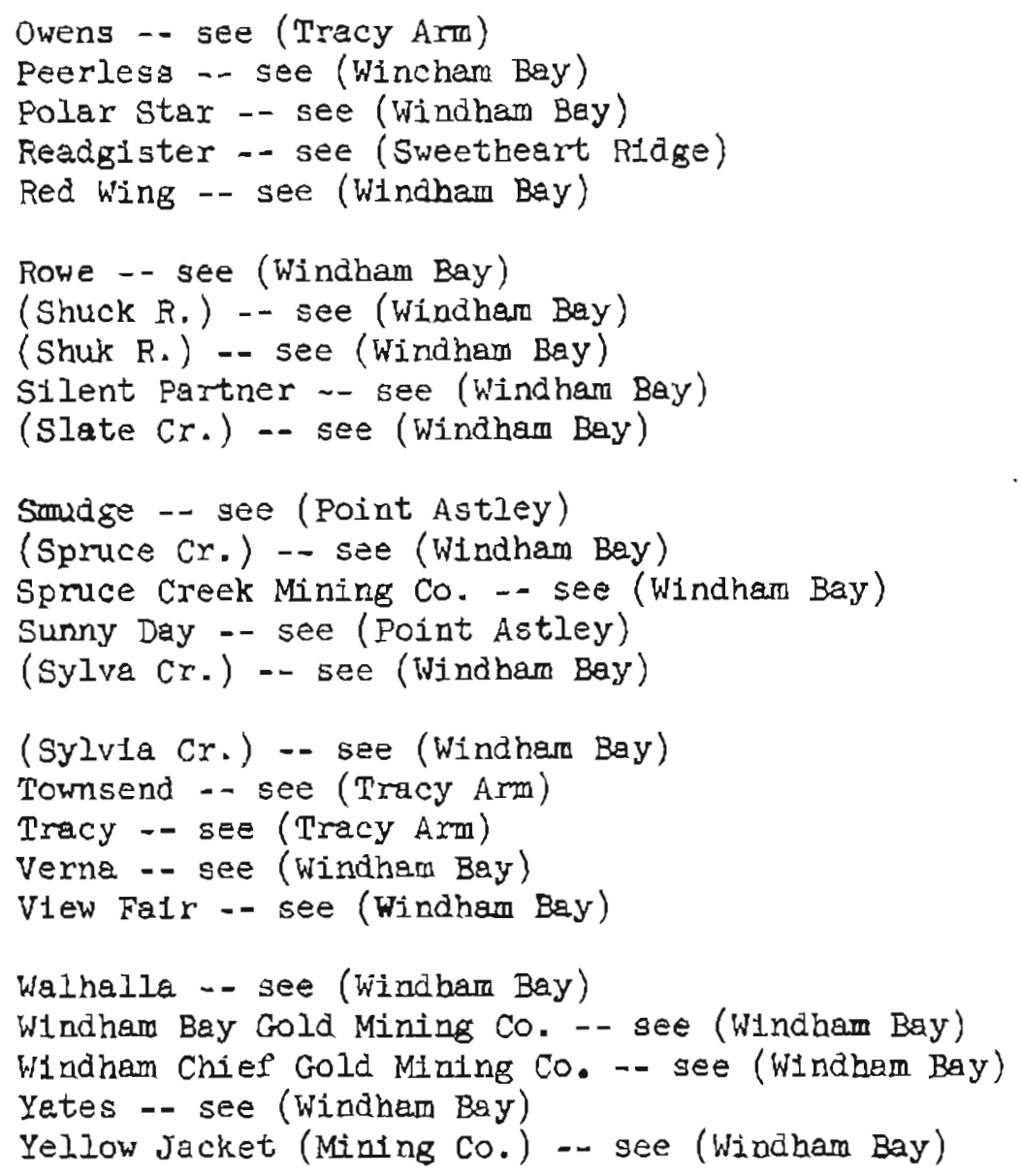




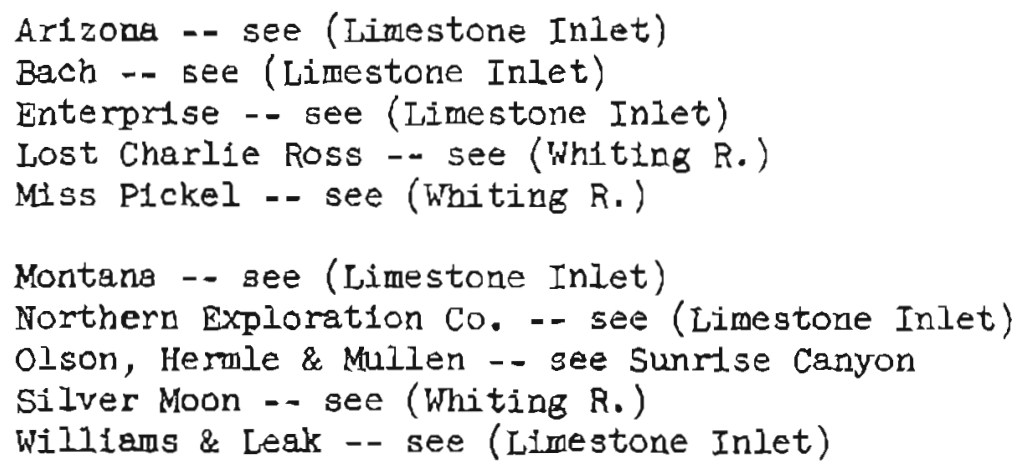




\section{References Cited}

References are listed in standard biblfographic iormat alphabetically by author and, secondarlly, chronologically if an author prepered more than one report or map. This section was prepared by stacklng bibliography caris in a document protector and duplicating them on an offlce copying machine. This procedure maked retyping unnecessary, but has the disadvantages that the edges of cards may reproduce as horizontal l1nes between entries and that marglns and spacing are not constant. 
Alaska Depertment of Mines, 1957, Report of the Comissloner of Mines for the biennium ended December 31, 1956: Juneau, Alaska, 103 p.

Bain, H. $\bar{s} ., 1946$, Alaska's merals as a basis for industry: U.S. Bureau of Mines Information Clrcular 7379, 89 p.

Becker, G. F., 18,8, , Reconnaissance of the gold fields of soutbern Alaska, with sone notes on general geology: U.S. Geological Survey leth Anaulal Report, pt. 3, p. 1-86.

Bers, H. C., anci Cobb, E. H., 1967, Metalliferous lode deposits of Alaska: U.S. Geologlcal Survey Bullet1n 1246, 254 p.

Brew, D. A., Grybeck, Donald, Johnson, B. R., Jachens, R. C., Natt, C. J., Barnes, D. F., Kimball, A. I., Still, J. C., and Rataj, J. L., 1977, Mineral resources of the Tracy Arm-Forda Terror wildemess study area and vicinity, Alaska: U.S. Geol. Survey open-file rept. $77-649,282$ g.

Brooks, A. 7., 1904, Placer mining in Alaska in 1903: U.S. Geological Survey Bulletin 225, p. 43-59.

Brooks, A. H., 1913, The mining industry in 1912! U.S. Geological Survey Bulletin 542, p. 18-51.

Brooks, A. R., 1921, The Aloskan mining Industry in 1920: U.S. Geologtcal Survey Bulletin 722, p. 7-67.

Brooks, A. H., 1923, The Alaska mining industry in 1921: 0.3. Geological Survey Bulletin 739, p. 1-44.

Brooks, A. R., and Capps, S. R., 1924, The Alaske mining industry in 1922: U.S. Geological Survey Bulletin 755, p. 3-49.

Buddington, A. $\vec{F} ., 1923$, Mirerel deposits of the Wrangell district: U.S. Geol. Survey Bull. 739, p. 51-75.

Buddington, A. F., 1925, Mineral investigations in soutbeastem Alaska: U.S. Geol. Survey Bull. 773, p. 71-139.

Buddington, A. F., and Chapin, Theodore, 1929, Geology and mineral depos1ts of soutbeastern Alaska: U.S. Geol. Survey Bull. 800, 398 p.

Cars, M. S., and Dutton, C. E., 1959, Iron-ore resources of the unt ted States 1ncluding Alaska and Puerto R1co: U.S. Geol. Survey Bull. $1082-C$, p. 61-134.

Chapin, Theodore, 1916, Mning developments in southeastem Alaska: U.S. Geol. Survey Bull. 642, 0.73-104. 
Clark, A. Y.., B:ı, I. i., Grybeck, D. A., and Wehr, Raymond, 1970, Araljum

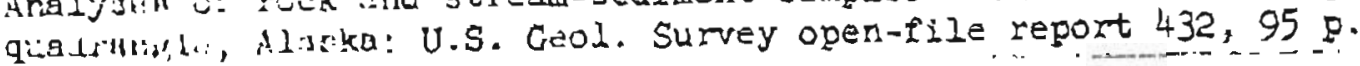

Clatk, A. L., ij..., D. A., crybeck, D. A., and wehr, Raymond, 1970, Analyst: it rock and stream-sediment samples from the sumdum $B-5$ quactink, Alaiks: U.S. Geol. Survey open-r1le report 434, 85 p.

Cobb, E. 4., iric, natallic mineral resources map of the sumdum quadraotr, hisku: U.S. Geal. Survey Misc. Field Studies Map MF-l.25, l iticel, scale 1:250,000.

Cobb, E. H., 29/i, Placer deposits of Alaska: U.S. Geological survey Bullatlı $1: i, 213 p$.

Eakins, C. R., ij/5, Uranium investigations is soutbeastern Alaska: Alaiku Ulv. Cco1. Geophys. Surveys Geol. Rept. 44, 62 p.

Flscher, F. F, ij15, Vanadium resources in titaniferous mapetite depislls: id.A. Geol. Survey Prof. Paper 926-B, p. Bl-Blo.

Gault, R. F., un Fellows, R. F., 1953, Zinc-copper depostt at Trecy

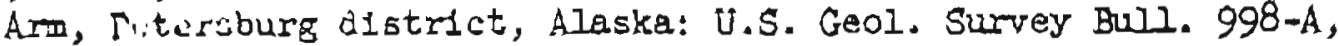
p. $1-13$.

Houston, J. A., Jates, R. G., Velikanje, R. S., and Wedor, Helmuth, Ir., $1 \%$, feconnaissance for radioactive deposits in southeastern Alaskin, lije: i.j. Geol. Survey Bull. 1058-A, p. 1-31.

Herbert, C. F., and sace, W. H., 1964, Geochemicel investigations of selecter areag in southeastern Aleska, 2964! Alaska DIv. Mines and linerals Geochem. Rept. 1, $27 \mathrm{p}$.

Rerreid, corion, 1962, Prelimdury report on geologie mappling in the Coast Range mineral belt, in Alaska Division of Mloes and Minorals, Report. for the year 1962: Juneeu, Alaska, p. 44-59, 62-67; also pub. as Geologle Rept. 1, 1962.

Kaufman, Alvin, 1958, Southeastern Alaska's maeral industry! U.S. Bur. Mines Inf. C1re. $7844,37 \mathrm{~g}$.

Knopf, Adolph, 1910, Mining in southeastern Alaska: U.3. Ceol. Survey Bui1. $442,9.133-143$.

Knopl, Adolph, 1911. M1njng In southeastern Alaska: U.S. Geol. Survey Bull. 480 , p. $94-102$.

Knopf, Adolph, 1912, The Eagle Rtver region, southeastern Alaska: U.S. Geol. Survey Bull. $502,61 \mathrm{~g}$. 
Boschmans, A. H., and Bergendehl, M. H., 1968, Principal gold-producing districts of the United States: U.S. Geol. Survey Prol. Paper 610, $283 \mathrm{p}$.

Meckevett, E. M., Jr., and Blake, M. C., Jr., 1964, Geology of the Sumdum copper-zinc prospect, southeastem Alaska: U.S. Geol. Survey Bull. 1108-E, D. El-E3l.

Martin, G. C., 1920, The Alaskan mining 1ndustry in 1918: U.S. Geological Survey Bulletin 712, p. 21-52.

Moff1t, F. H., 1927, Mineral industry of Alaska in 1925: U.S. Ceological Survey Bulletin 792, p. 1-39.

Noel, G. A., 1966, The productive mineral deposits of southeastern Alagka, In Alaska Division of Mines and Minerals, Report for the year 1966: Juneau, Alaska, p. 51-57, 60-68.

Page, N. J, Clark, A. L., Desborough, G. A., and Parker, R. L., 1973, Platinum-group metals, In Brobst, D. A., and Pratt, H. P., eds., United States mineral resourcus! U.S. Geol. Survey Prof. Poper 820, p. 537-545.

Race, W. H., 1962, Preliminars geocbemical investigation, Tracy and Endicott Arm area, in Alaska Division of Mines and Minerals, Report for the year 1962: Juneau, Alaska, p. 68-74.

Race, $W$. T., and Roge, A. W., 1967, Geochemical and geological 1nvestigation of Adriralty Island, Aleska: Alaska Div. Mines anà Minerals Geocher. Rept. $8,43 \mathrm{p}$.

Spencer, A. C., 1904, The Juneau golit belt, Alaska: U.S.: Geol. Survey Bul1. 225, p. $28-42$.

Spencer, A. C., 1906, The Juneau gold belt, Alaska: U.S. Geol. Survey Bull. 287, p. 1-137.

Solth, P. S., 1929, Mine ral 1ndustry of Alaska in 1926: U.S. Geological Survey Bulletin 797, p. 1-50.

Smith, P. S., 1930, Mineral industry or Alaska in 1927! U.S. Gaolog1cal Survey Bulletin 810, p. 1.64.

Smith, P. S., 1930, Mineral 1ndustry of Alaske in 1928: U.S. Geolog1cal survey Bulletin 813, p. 1-72.

Smlth, P. S., 1932, Mineral 1ndustry of Alaska in 1929: U.S. Ceolog1cal Suivey Bulletin 824, g. 1-81.

Smitb, P. S., 1934, Muneral Industry of Alaska in 1932: U.S. Ceolo. gical Survey Julletin 857-A, p. 1-91.

Smtth, P. B., 1934, Mineral iminstiy of Alaska in 1933: U.5. Geological survey Julietin $36 \%-A, \xi .1-94$. 
Smith, P. S., 1936, Mineral incustry of Alaska in 1934: U.3. Geological Survey Bulletin 868-A, p. 1-91.

Sutth, P. S., 1937, Mineral industry of Alaska in 1935: U.S. Geolo. sical Surrey Bulletin 880-A, p. 1-95.

Soith, P. S., 1938, Mineral industry of Alaska in 1936: U.S. Geological Survey Bullet1n 897-A, p. 1-107.

Smith, P. S., 1939, Mineral industry of Alaska in 1937: U.S. Coolog1cal Survey Bulle tia 910-A, p. 1-113.

Smlth, P. S., 1942, Mineral Industry of Alaska in 1940: U.S. Ceological Survey Buzletio 933-A, p. 1-102.

Smitb, s. S., 1,17, The mintng industry in the Territory of Alaska durlng the calender year 1916: U.S. Bureau of Mines Bulletin $153,89 \mathrm{p}$.

Thome, R. L., and Wells, R. R., 1956, Studies of the Snettisham magnet1te deposit, southeastem Alacka: U.S. Bur. Mines Rept. Inv. 5195, 41 p.

Twenhofel, W. S., 1953, Potential Alaskan mineral resources for proposed electrochemical and electrometallurgical ladustries In the upper Lumn Canal area, Alaska: U.S. Geol. Survey ctre. $252,14 \mathrm{p}$.

U.S. Geologleal survay, 1962, Geological survey research 1962: U.S. Geological sur:cy Professional Paper 450-A, p. Al-A257.

Wedow, Helwith, ir., and otbers, 1953, Prelimtnary summary of reconnalssance for uranium and thorlum 1a Alaska, 1952: U.S. Geol. survey c1re. $248,15 \mathrm{p}$.

Wedow, Felmenth, Jr., White, M. G., and Moxham, R. M., 1952, Inter1m report on an appralsal of the uranium posslbilities of Alaska: U.S. Crological Survey Open-file Report 51, 123 p.

Wright, C. W., 1907, Lode mining in southeastern Alaska: U.S. Geol. Suriey Bull. 314, p. 47-72.

Wright, C. '., 1908, Lodo mining in southeastem Alaska, 1907: U.S. Geol. Survey Bull. 345, p. 78-97.

Wright; C. W., 1909, Mining in southeastem Alaska: U.S. Geol. Survey Bull. 37\%, p. 67-86.

Wrlght, F. E., and kight, C. W., 1905, Economic developments in southeastern Alaska: U.S. Geol. Survey Bull. 259, p. $47-68$.

Wrtght, F. E., and Wright, C. W., 1906, Lode mining in southeestern Alaska: U.S. Geol. Survey Bull. 284, p. 30-54. 
Berg, H. C., and Cobb, E. H., 1967, Metall1ferous lode deposits of Alaska: U.S. Geol. Survey Bull. 1246, 254 p.

Brew, D. A., and Ford, A. B., 1969, Boundary Creek molybdenumstiver occurrence, in Some sborter mineral resource investigations in Alaska: U.S. Geol. Survey CIre. 615, p. 12-15.

Brew, D. A., Grybeck, Donald, Jchnson, B. R., Jachens, R. C., Nutt, C. I., Barnes, D. F., Kimball, A. L., St1ll, J. C., and Rata\}, J. L., 1977, Mineral resources of the Tracy Arm-Fonds Terror wilderness study aree and vicinity, Alaska: U.S. Geol. Survey open-11le rept. $77-649,282 \mathrm{p}$.

Buddington, A. F., 1925, Mineral investigations in southeastern Alaska: U.S. Geol. Surrey Bull. 773, p. 71-139.

Buddington, A. F., and Chapin, Theodore, 1929, Ceology and mineral deposits of southeastern Alaska: U.S. Geol. Survey Bull. 800,398 p.

Chepin, Theodore, 1916, Xining developments in southeastern Aleska: U'.s. Geol. Survey Bull. 642, g. 73-104.

Cobb, H. H., 1972, Metalite wineral resources of the raku River quadrangle, Alaska! U.S. Geol. Survey Misc. Fleld Studies Map MF-407, I sheet, scale 1:250,000.

Eakin, H. M., 1918, Lode mining in the Juneau gold belt: U.S. Geol. Survey Bull. 662, p. 77-92.

Kaufman, Alvin, 1958; Southeastern Aleska's mineral industry: U.S. Bur. Mines Inf. C1re. 7844, 37 p.

Knopf, Adolph, 1910, Mining in southeastern Alaska: U.S. Ceol. Survey Busl. 442, p. 133-143.

Knopf, Adolph, 1311, Mining in 5outheastern Alaska! U.S. Geol. Survey Bull. 480, p. 94-102.

Plttman, T. L., 2957, Reconnalssance examination of Sunrise Canyon manganege, Slocum Inlet, Alaska: U.S. Bur. Mines open-pIle rept., 7 p.

Smith, 9. S., 1917, The mining dndustry in the Territory of Alaska durlag the calendar year 1916: U.S. Bur. Mines Bull. 153, 89 p.

Wedow, Helmuth, Ir., White, M. G., and Moxhem, R. M., I95e, Intertio report on an eppraisal of the uranium possibilities of Alaska: U.S. Geol. Survey open-file report $51,123 \mathrm{p}$. 
Wright, C. W., 1908, Lode minting in southeastern Alaska, 1907: U.S. Geol. Survey Bull. 345 , p. $79-97$.

Wrlgbt, C. W., 1909, Mining in southeastern Alaska! U.S. Geol. Survey Bu21. 379, p. 67-86. 